Facsimile Price $\$ 5.60$
Microfilm Price $\$, ~$
Available from the
Office of Technical Services
Department of Commerce
Washington 25, D. C.

\title{
FISSION FRAGMENT ENERGY DEPOSITION EFFICIENCY \\ FOR THIN URANIUM-CONTAINING ELEMENTS AND THE \\ FIXATION OF NITROGEN
}

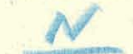

by

Meyer Steinberg,* Marco Loffelholz, and Jacob Pruzansky

\section{Brookhaven National Laboratory Upton, New York}

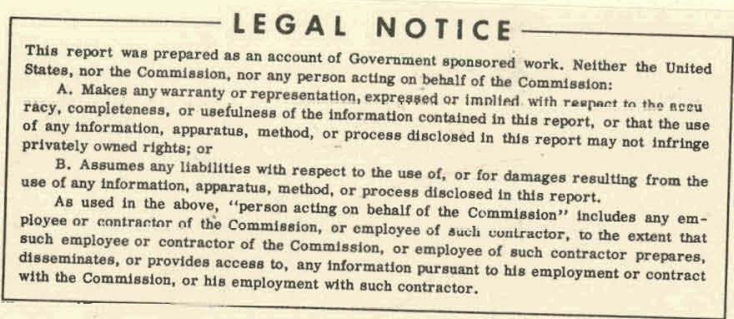

March, 1963

Work Ferformcd Under the Auspices of the Division of the Reactor Development, U.S. Atomic Energy Commission 


\section{DISCLAIMER}

This report was prepared as an account of work sponsored by an agency of the United States Government. Neither the United States Government nor any agency Thereof, nor any of their employees, makes any warranty, express or implied, or assumes any legal liability or responsibility for the accuracy, completeness, or usefulness of any information, apparatus, product, or process disclosed, or represents that its use would not infringe privately owned rights. Reference herein to any specific commercial product, process, or service by trade name, trademark, manufacturer, or otherwise does not necessarily constitute or imply its endorsement, recommendation, or favoring by the United States Government or any agency thereof. The views and opinions of authors expressed herein do not necessarily state or reflect those of the United States Government or any agency thereof. 


\section{DISCLAIMER}

Portions of this document may be illegible in electronic image products. Images are produced from the best available original document. 


\section{Abstract}

The fission fragment energy deposition efficiency of U-containing glass fibers in a two-dimensional oriented array and in a random array of wool, and U-containing metal alloys of Al and Pd, has been determined with the use of the gaseous nitrous oxide dosimeter. The $\mathrm{N}_{2} \mathrm{O}$ dosimeter was first calibrated in a co 60 gamma field and was found to be independent of pressure up.to 37 atm, but dependent on total dose. Energy expressions have been derived for the dosimeter as a function of product concentration. The pile neutron and gamma radiation, the proton radiation from the $\mathrm{N}^{14}(n, p) \mathrm{c}^{14}$ reaction, and by difference, the fission fragment recoil radiation were then determined in a nuclear reactor. The energy deposition efficiency from the two-dimensional fission sources was found to be dependent on geometry of the source and the containment vessel, the thickness or weight loading of the source, and the range of the fission fragment in the source. The efficiency for the foil elements is in reasonable agreement with analytical results based on average fission fragment range data. Further study is needed to indicate whether the linear or the quadratic model is better suited for energy deposition efficiency analysis. The maximum observed efficiency obtained for an oriented array of U-glass fiber was 39\%; for the glass wool, $43 \%$; for the $27.6 \% \mathrm{U}-\mathrm{Al}$ foil, 39\%; and for the $18.3 \% \mathrm{U}-\mathrm{Pd}, 52.4 \%$. The unperturbed efficiency for the latter is $63 \%$. 
The fission sources were used for irradiations of a $77 \% \mathrm{~N}_{2}+23 \% \mathrm{O}_{2}$. gas mixture. The fission fragment $\mathrm{G}\left(\mathrm{NO}_{2}\right)$ value ranges from 0.5 to 1.7 at $25^{\circ} \mathrm{C}$ in the pressure interval 0.6 to 73 atm, with no significant trend with pressure. The corresponding $\mathrm{G}\left(\mathrm{N}_{2} \mathrm{O}\right)$ value varies between 0.5 and 2.1 . The fission fragment $\mathrm{G}\left(\mathrm{NO}_{2}\right)$ value is not very different from that obtained with lower LET pile and Co ${ }^{60}$ gamma radiation. However, the $\mathrm{G}\left(\mathrm{N}_{2} \mathrm{O}\right)$ is found to increase with higher LET heavy particle radiation. The results obtained when using sources and claddings of increasing thickness do not indicate significantly higher $G$ values for $\mathrm{NO}_{2}$ and $\mathrm{N}_{2} \mathrm{O}$ formation when mainly utilizing the energy available toward the latter part of the fission track. Further study in static and dynamic systems is needed to firmly establish yields as a function of temperature and pressure. 


\section{FISSION FRAGMENT ENERGY DEPOSITION EFFICIENCY}

\section{FOR THIN URANIUM-CONTAINING ELEMENTS AND THE}

\section{FIXATION OF NITROGEN}

by

Meyer Steinberg, Marco Loffelholz, and Jacob Pruzansky

\section{Introduction}

When evaluating the use of fission fragment recoil

energy for the production of chemicals in chemonuclear processes, an important piece of information needed is the yield of the chemical product formed as a function of the energy deposited in the system. In the design of chemonuclear reactors, as well as in fission fragment radiation chemistry experiments, a source containing $U$ in the form of a solid substrate is usually placed in intimate contact with the chemical reactant. Although homogeneous gaseous or liquid U fuel systems can be used for this purpose, the more technologically developed systems are those which are either in an oriented or random array of solids arranged in a fixed position with respect to the chemical reactant. In these systems, the efficiency of conversion of nuclear to chemical energy is directly related to the fraction of the total fission fragment recoil energy liberated in the system, which is 
directly absorbed by the chemical reactant. This fraction is termed the fission fragment energy deposition, $€ / 100$. Since the fission fragment recoil energy accounts for approximately $85 \%$ of the total energy released in fission, the total energy deposition efficiency, designated as $\epsilon_{0}$ is thus $0.85 \epsilon$. This paper describes the use of gas dosimetry for determining the deposition efficiency, and gives $G$ value data for the fixation of nitrogen by fission fragment energy.

Because of the simplicity and the relative precision that can be obtained, liquid chemical dosimetry, as exemplified by the ferrous sulfate Fricke dosimeter, (6) has been found acceptable for measuring high energy radiation deposited in liquid systems. Applying similar criteria, when working in the gas phase, it is useful to employ a gas dosimeter which would simulate, as near as possible, the geometric and physical conditions of the gas system to be determined. Nitrous oxide has been proposed as one of the more suitable gases for dosimetry work. (2) The $\mathrm{N}_{2} \mathrm{O}$ dosimeter has the advantage of producing only gaseous products consisting mainly of $\mathrm{N}_{2}, \mathrm{O}_{2}$, and $\mathrm{NO}_{2}$. It has been found to be independent of type of radiation absorbed, i.e., co ${ }^{60}$ y rays, x rays, electrons, a xays, pile radiation, and fission fragments, $(3,4,5,10,11)$ and a number. of attempts have been made for calibrating it against other recognized dosimetry standards. $(5,6,7)$ It has been found to be independent of dose rate, but dependent on total dose. $(7,8)$ pressure and temperature limitations $(4,5,9)$ have also been observed. Temperatures above $150^{\circ} \mathrm{C}$ cause increased thermal decomposition of 
$\mathrm{N}_{2} \mathrm{O}$ gas and at $25^{\circ} \mathrm{C}$ the operating pressure is limited by the vapor pressure which is 56 atm.

A well known difficulty in measuring $G$ values, based on fission fragment energy inside a reactor, has been the simultaneous effects of the concomitant gamma and fast neutron radiations, in addition to secondary radiations caused by neutron absorption reactions. When using a gas dosimeter containing nitrogen, as is the case for the nitrous oxide dosimeter, the thermal neutron cross section of nitrogen ( $1.8 \mathrm{~b}$ ) is appreciable and gives rise to a reaction emitting $0.6-\mathrm{Mev}$ protons. These are capable of depositing significant quantities of energy in the chemical system. The procedure adopted in this study for calibration and sorting out the several types of in-pile radiation was as follows:

1. The $\mathrm{N}_{2} \mathrm{O}$ gas dosimeter was calibrated against the ferrous sulfate dosimeter $\left[\mathrm{G}\left(\mathrm{Fe}^{++} \mathrm{F}^{+++}\right)=15.6\right]$ in a $\mathrm{Co}^{60} \mathrm{gamma}$ field (initial $Y$ energy $=1.33$, and $1.17 \mathrm{Mev}$ ).

2. The $\mathrm{N}_{2} \mathrm{O}$ gas dosimeter was used in-pile for evaluation of the total energy deposited due to the pile $n, \gamma$ energy and the $\mathrm{N}^{14}(\mathrm{n}, \mathrm{p}) \mathrm{c}^{14}$ redctiun.

3. Pure $\mathrm{CO}_{2}$ gas inhibited with $0.5 \% \mathrm{NO}_{2}$ was used to evaluate the pile $n, y$ energy using a $G(C O)$ value of $3.7 .(12,13)$ 4. The $\mathrm{N}_{2} \mathrm{O}$ gas dosimeter was used in-pile with a $\mathrm{U}^{235}-$ containing fission fragment source to obtain total energy deposited which includes the $n, p+n, \gamma+F . F$. energy. 
5. The fission fragment energy deposited was obtained by subtracting the $n, p$ and $n, y$ energy determined in 2 above from the total found in 4 .

6. The total fission energy deposited in the U-containing systems was calculated from the thermal neutron flux which was determined by activation analysis of $\mathrm{Mn}^{55}$, (15) the concentration of $\mathrm{U}^{235}$, and the fission cross section of $\mathrm{U}^{235}$.

After determining the energy deposited, the same fission source was used in irradiating the gaseous $\mathrm{N}_{2}$ and $\mathrm{O}_{2}$ mixture. The yield due to the $n, p$ and $n, y$ reactions (determined in the gamma field) was deducted from the total yield to arrive at a fission fragment $G$ value for the formation of the product.

\section{Experimental Procedure}

For pressures below $\approx 5$ atm, quartz (or glass in the gamma field) break seal vessels of the order of 20 to 35-cc capacity were used to contain the gas and the U fission fragment source (Figure 1). $\mathrm{N}_{2} \mathrm{O}$ gas taken from a Matheson Gas Co. cylinder was purified before usé in a vacuum rack by a sequence of condensing at $-196^{\circ} \mathrm{C}$, pumping, distilling part of the condensate at $-78^{\circ} \mathrm{C}$, and then recondensing at $-196^{n} \mathrm{C}$.

Compressed gas mixtures of $\mathrm{N}_{2}$ and $\mathrm{O}_{2}$ from pre-purified pressurized Matheson Gas Co. cylinders were used without further purification. A mass spectrometer analysis indicated impurities consisting of $0.07 \% \mathrm{Ar}$ and $0.04 \% \mathrm{H}_{2} \mathrm{O}$ in the $76.7 \% \mathrm{~N}_{2}+23.2 \% \mathrm{O}_{2}$ mixture used in the quartz and glass capsules, while $0.9 \% \mathrm{Ar}$, 
$0.05 \% \mathrm{H}_{2} \mathrm{O}$, and $0.11 \% \mathrm{CO}_{2}$ was found in the $76.2 \% \mathrm{~N}_{2}+22.7 \% \mathrm{O}_{2}$ mixture used in the Al vessels.

Above 5 atm and up to 75 atm, high purity Al vessels of $\approx 35$ to 40-cc capacity were used both for dosimetry and $\mathrm{N}_{2}$ and $\mathrm{O}_{2}$ irradiations as shown in Figure 2. An Al valve body with a stainless steel needle stem and Teflon gasket was used to seal the Al vessels. The stem and gasket were replaced periodically.

Vessel filling and gas analysis were performed by vacuum rack techniques. An Alphatron gauge was used for most of the pressure measurements. The Alphatron was calibrated both with a Hg manometer and a Precision Wallace and Tiernan Bourdon tube gauge. Appropriate calibrated correction factors for the type of gas and for cooling portions of the rack were applied. The rack assembly is shown in Figure 4. In the case of filling the vessel with a $\mathrm{N}_{2}+\mathrm{O}_{2}$ mixture, a $\mathrm{He}$ sparged liquid nitrogen bath was used to lower the temperature. A mass spectrometeric analysis, after filling, compared closely with an analysis of gas from the supply cylinder.

After irradiation, in the case of the quartz and glass capsules, the entire capsule was enclosed in another ground glass sealed container, having an internal protrusion for purposes of breaking the capsule seal. The capsule seal was broken by impact, the container was brought to liquid nitrogen bath temperature, connected to the vacuum rack, and the noncondensible $\mathrm{N}_{2}$ and $\mathrm{O}_{2}$ measured. The contents were then brought to dry ice-acetone bath temperature $\left(-78^{\circ}(-)\right.$ and the $\mathrm{N}_{2} \mathrm{O}$ pressure measured. Finally, the vessel was brought 
to room temperature $\left(25^{\circ} \mathrm{C}\right)$ and the $\mathrm{NO}_{2}$ measured. Since $\mathrm{NO}_{2}$ has a tendency to adsorb slowly on the surface of the vacuum rack, a recorder was used for detecting initial maximum reading of $\mathrm{NO}_{2}$ indicated by the Alphatron pressure gauge; this reading was used for the yield calculations. Additional precautions and corrections were made when determining $\mathrm{NO}_{2}$, as follows. Care was taken not to evacuate the system below $630 \mathrm{\mu}$ after evacuating the $\mathrm{N}_{2} \mathrm{O}$ at $-78^{\circ} \mathrm{C}$, since this is approximately the vapor pressure of $\mathrm{NO}_{2}$ at this temperature. Further, a correction for $\mathrm{NO}_{2}$ association to $\mathrm{N}_{2} \mathrm{O}_{4}$ was made by using thermodynamic data, (16) when the pressure was sufficiently high to warrant it. For example, at room temperature the association correction for $\mathrm{NO}_{2}$ is $10.6 \%$, when the vacuum rack pressure measurement for $\mathrm{NO}_{2}$ plus $\mathrm{N}_{2} \mathrm{O}_{4}$ is $7.6 \mathrm{~mm}$.

The filling procedure for the Al vessels was similar to that for the quartz vessels; however, for analysis, a glass U-shaped tube transfer trap immersed in liquid nitrogen was used to trap out the $\mathrm{N}_{2} \mathrm{O}$ and $\mathrm{NO}_{2}$. In the case of the high pressure irradiations of $\mathrm{N}_{2}$ and $\mathrm{O}_{2}$, a large volume expansion bulb was connected to the rack. For the gamma field irradiations, the BNL Co ${ }^{60}$ gamma pool facility was used. Calibration was performed within the vessels by means of ferrous sulfate dosimetry. For the in-pile irradiations, a water-cooled experimental hole was used in the Brookhaven Graphite Research Reactor. The temperature was controlled in the hole between $25^{\circ}$ and $30^{\circ} \mathrm{C}$. After in-pile irradiation, the capsule's were usually allowed to cool for a period of $\approx 1$ week before analysis, so that direct handling was possible. 
The integrated energy deposited during the cooling period is estimated to be less than a maximum of $5 \%$ of the total deposited during the in-pile irradiation. (17)

A number of fission fragment sources were used for the capsule experiments. These included U containing (1) glass fiber, (2) glass wool, (3) Al alloy metal foil, and (4) Pd alloy metal foil. The significant information for these sources are listed in Table I. The manufacturing method for the U glass included drawing the molten glass through a Pt die and blowing into a basket when forming a random array of fibers in the form of wool, or winding on an 8 in. fiber cylinder when forming an oriented two-dimensional array of fibers. In the latter form, the density of $U$ per unit area referred to as "weight loading" (mg $\mathrm{U}^{235} / \mathrm{cm}^{2}$ ) was produced by adjusting the density of winding of the fibers on the cylinder. For the U-Al alloy a four-high rolling mill was used to roll heavier plate to thicknesses of 0.5 and $0.25 \mathrm{mil}$ (12.7 and $6.3 \mathrm{\mu}$, respectively). In the case of the U-Pd solid solution alloy, the final rolling to $0.16 \mathrm{mil}$ ( $4 \mu$ ) was performed on a sendzimir mill: Finer thicknesses were produced by etching and electropolishing. Wet chemical analysis for $\mathbf{U}$ content indicated no preferential etching. Thicknesses heavier than $0.16 \mathrm{mil}$ were made by combining layers of thinner foils.

- The glass wool was distributed throughout the quartz capsule, as shown in Figure 1, and is thus essentially a three-dimensional element in random array. The glass fiber and metal foils were supported peripherally by friction between two quartz rings, 
shown in Figure 3, and is essentially in an oriented two-dimensional array. The rings were supported in the capsules as shown in Figures 1 and 2 .

Experimental and Calculated Results

The partial pressure data obtained in the $\mathrm{N}_{2} \mathrm{O}$ dosimetry measurements lead to the following analysis:

$$
\begin{aligned}
\mathrm{p} & =\mathrm{p}\left(\mathrm{NO}_{2}\right)+\mathrm{p}\left(\mathrm{N}_{2}+\mathrm{O}_{2}\right)+\mathrm{p}\left(\mathrm{N}_{2} \mathrm{O}\right), \\
\mathrm{p}\left(\mathrm{N}_{2}\right) & =0.5 \mathrm{p}\left(\mathrm{NO}_{2}\right)+0.667 \mathrm{p}\left(\mathrm{N}_{2}+\mathrm{O}_{2}\right), \\
\mathrm{p}\left(\mathrm{O}_{2}\right) & =0.33 \mathrm{p}\left(\mathrm{N}_{2}+\mathrm{O}_{2}\right)-0.5 \mathrm{p}\left(\mathrm{NO}_{2}\right), \\
\mathrm{p}\left(\mathrm{N}_{2} \mathrm{O}\right)_{\mathrm{D}} & =\mathrm{p}\left(\mathrm{N}_{2}\right)+0.5 \mathrm{p}\left(\mathrm{NO}_{2}\right),
\end{aligned}
$$

where:

$$
\begin{array}{ll}
\mathrm{P} & =\text { total pressure, } \mathrm{mm} \mathrm{Hg}, \\
\mathrm{p}(\mathrm{)} & =\text { partial pressure, } \mathrm{mm} \mathrm{Hg}, \text { and } \\
\dot{\mathrm{p}}\left(\mathrm{N}_{2} \mathrm{O}\right)_{\mathrm{D}}= & \text { the equivalent partial pressure of } \mathrm{N}_{2} \mathrm{O} \text { which was } \\
& \text { decomposed during irradiation, } \mathrm{mm} \mathrm{Hg}^{\circ}
\end{array}
$$

The above assumes that only three products are formed in the dosimeter, namely, $\mathrm{NO}_{2}, \mathrm{~N}_{2}$, and $\mathrm{O}_{2}$. Mass balances by using the above equations indicated fair agreement with this assumption, In addition, gas chromatographic analysis made in several runs specificalIy for $\mathrm{N}_{2}$ concentration was in reasonable agreement with that calculated from partial pressure measurements and the above equations. other work ${ }^{(9)}$ has also indicated negligible amounts of No formation. 
In the case of the $\mathrm{NO}_{2}$ analysis in the Al vessels, it was observed that when the vessel was initially used, $\approx 18 \%$ of the $\mathrm{NO}_{2}$ formed during an average irradiation experiment was found fixed to the walls of the vessel. This was determined by dilute caustic washings of the vessel and analyzing the washings for total nitrate and nitrite. (18). Subsequent to this initial absorption of $\mathrm{NO}_{2}$, there was no further absorption or desorption. Similar results were obtained when cylinder $\mathrm{NO}_{2}$ gas was used to. pre-condition the Al vessels. The initial charge of $\mathrm{NO}_{2}$ caused absorption, but subsequent charges did not:

I. Calibration of the $\mathrm{N}_{2}$. Gas Dosimeter in a Co 60 Gamma Source. Table II shows the experimental and calculated data for the calibration of the $\mathrm{N}_{2} \mathrm{O}$ dosimeter. It is noted that the absorbed dose is $10 \%$ lower than the total dose indicated by the Fricke dosimeter (the ratio of the electron density for $\mathrm{N}_{2} \mathrm{O}$ to that of $\mathrm{H}_{2} \mathrm{O}$ is $15 / 30$ to $\left.10 / 18=0.9\right)$. In the case of the Al cylinder, the shielding due to the wall thickness reduces the dose rate an additional 15\%. The concentrations of $\mathrm{NO}_{2}, \mathrm{~N}_{2}$, and $\mathrm{N}_{2} \mathrm{O}$ decomposed are plotted in Figures 5, 6, and 7, respectively, as a function of the total dose in rad/hr. Equations were fitted to the data and converted to a convenient. form for calculating absorbed energy as follows:

$$
\begin{aligned}
E\left(\mathrm{NO}_{2}\right) & =3.80 \times 10^{21} \mathrm{w}_{\mathrm{g}}\left[\% \mathrm{NO}_{2}\right], \\
\mathrm{E}\left(\mathrm{N}_{2}\right) & =1.59 \times 10^{21} \mathrm{w}_{\mathrm{g}}\left[\% \mathrm{~N}_{2}\right]^{1.064,} \\
\mathrm{E}\left(\mathrm{N}_{2} \mathrm{O}\right)_{\mathrm{D}} & =1.34 \times 10^{21} \mathrm{w}_{\mathrm{g}}\left[\%\left(\mathrm{~N}_{2} \mathrm{O}\right)_{\mathrm{D}}\right]^{1.04},
\end{aligned}
$$


where:

$$
\begin{aligned}
& E()=\text { the energy absorbed in the gas based on the chemical } \\
& \mathrm{w}_{\mathrm{g}} \quad=\text { weight of gas, } \mathrm{g} \text {, } \\
& {[\%]=\text { volume } \% \text { concentration of } \mathrm{NO}_{2}, \mathrm{~N}_{2} \text {, or }\left(\mathrm{N}_{2} \mathrm{O}\right)_{\mathrm{D}} \text {. }}
\end{aligned}
$$

The above equations indicate that in the interval of 0.1 to $10 \%$ volumetric concentration of the $\mathrm{NO}_{2}, \mathrm{~N}_{2}$, and $\left(\mathrm{N}_{2} \mathrm{O}\right)_{\mathrm{D}}$ products of the $\mathrm{N}_{2} \mathrm{O}$ dosimeter, the $\mathrm{G}$ value for $\mathrm{NO}_{2}$ formation is constant (in the order of 3.6), while the $\mathrm{G}$ value for $\mathrm{N}_{2}$ formation and $\mathrm{N}_{2} \mathrm{O}$ decomposition is dose dependent. The data also indicate that increasing pressure, in the range 1 to $37 \mathrm{~atm}$, has no significant effect on the dosimeter.

Although an advantage of the $\mathrm{N}_{2} \mathrm{O}$ dosimeter is that all the products are gaseous, the disadvantage is related to establishing which product component should be used for calibration. No 2 is reactive and probably contains the largest analytical error. $\mathrm{N}_{2}$ is the least reactive; however, if manometric analysis is used without separating and removing the $\mathrm{O}_{2}$ from the $\mathrm{N}_{2}$, the composition is still partially dependent on the $\mathrm{NO}_{2}$ when using the mass balance. Probably the most direct and simplest way is to analyze the $\mathrm{N}_{2}$ in one step by gas chromatography. The $\mathrm{NO}_{2}$ will be removed by the adsorbent and should not interfere, however, replacement of adsorbent columns due to $\mathrm{NO}_{2}$ may be required at more frequent intervals. In this study, partial pressure manometric analyses were 
made throughout and only an occasional parallel analysis on the gas chromatograph was used. In calculating the results all three species were used, although the $\left(\mathrm{N}_{2} \mathrm{O}\right)_{D}$ calibration is favored since this tends to average the errors in the $\mathrm{NO}_{2}$ and $\mathrm{N}_{2}$ measurements. The maximum deviation from equation (6) as derived from the line given in Figure 7 is $11 \%$. It is interesting to note that D. A. Landsman ${ }^{(8)}$ has correlated a mass of data on the $\mathrm{N}_{2} \mathrm{O}$ dosimeter and has come to the conclusion that the best equation expressing the $\mathrm{N}_{2}$ analysis is as follows:

$$
E\left(\mathrm{~N}_{2}\right)=1.73 \times 10^{21} \mathrm{w}_{\mathrm{g}}\left[\% \mathrm{~N}_{2}\right]^{1.064},
$$

which is only $8.8 \%$ higher than that given by equation (5) (Figure 6 in this study).

It should be noted that below $10 \%$ concentration by volume, the maximum deviation in either using the gas composition directly, or referring it back to the initial $\mathrm{N}_{2} \mathrm{O}$ volume, is $3 \%$. This deviation calculation is based on an average $\mathrm{N}_{2} / \mathrm{O}_{2} / \mathrm{NO}_{2}$ ratio of 1.0/0.10/0.52 determined from Table II.

Although $\mathrm{N}_{2} \mathrm{O}$ is far from an ideal gas for use in a dosimeter, a number of investigators have already indicated that it can be used satisfactorily. It is suggested that an investigation be undertaken by several laboratories to consider standardizing the $\mathrm{N}_{2} \mathrm{O}$ gas dosimeter. For heavy ion and fission fragment irradiation, particle counting and energy analysis, in addition to calorimetry, is being considered. for establishing absolute calibration. 
II. Pile Radiatiọn Dosimetry with $\mathrm{N}_{2} \mathrm{O}$.

A series of runs with the $\mathrm{N}_{2} \mathrm{O}$ dosimeter was made in quartz capsules to determine the total pile radiation (fast neutron and gamma $=n, y$. energy) and the $\mathrm{N}^{14}(\mathrm{n}, \mathrm{p}) \mathrm{c}^{14}$ radiation, as shown in Table III. The data indicate that in 10 runs at pressures of 1.8 to $3.0 \mathrm{~atm}$ over the flux range 5.9 to $7 \times 10^{12} \mathrm{n} / \mathrm{cm}^{2} / \mathrm{sec}$ and $\mathrm{ir}-$ radiation intervals from 1 to $24 \mathrm{hr}$, the average dose rate is equivalent to $1.40 \times 10^{21} \mathrm{ev} / \mathrm{g} / \mathrm{hr}\left(22.49 \times 10^{6} \mathrm{rad} / \mathrm{hr}\right) \cdot$ with a maximum deviation of $\pm 20 \%$. This may in part be due to flux variations during a run. The average $\mathrm{N}_{2} / \mathrm{O}_{2} / \mathrm{NO}_{2}$ ratio in these runs is in the order of $1.0 / 0.15 / 0.49$, which indicates a higher $\mathrm{O}_{2}$ ratio than found in the co ${ }^{60}$ gamma field.

III. Pile Radiation Dosimetry with $\mathrm{CO}_{2}$.

Table IV gives the data for two runs in which $\mathrm{CO}_{2}$ (inhibited with $0.5 \% \mathrm{NO}_{2}$ ) was used to determine the fast neutron and gamma radiation absorption. By using a $G(\mathrm{CO})$ value of 3.7, the energy absorbed is calculated from the following:

$$
E(C O)=3.70 \times 10^{21} w_{g}[\% \mathrm{Co}] \text {. }
$$

The average energy at $7 \times 10^{12} \mathrm{n} / \mathrm{cm}^{2} / \mathrm{sec}$ is $0.39 \times 10^{21}$ $\mathrm{ev} / \mathrm{g} / \mathrm{hr}\left(6.2 \times 10^{6} \mathrm{rad} / \mathrm{hr}\right)$ with a $\pm 6 \%$ maximum deviation for a twofold variation in in-pile exposure time. This value of the $n, y$ intensity is in line with calorimetric measurements made by Floyd, et al. (15) in the BNL reactor at a flux level of $1.2 \times 10^{13}$ $\mathrm{n} / \mathrm{cm}^{2} / \mathrm{sec}$, who obtained a value of $0.62 \times 10^{21} \mathrm{ev} / \mathrm{g} / \mathrm{hr}\left(10 \times 10^{6} \mathrm{rad} / \mathrm{hr}\right)$ : 
IV. The Energy Due to the $\mathrm{N}^{14}(\mathrm{n}, \mathrm{p}) \mathrm{C}^{14}$ Reaction.

Deducting the $\mathrm{CO}_{2}$ dosimetry measurement from the $\mathrm{N}_{2} \mathrm{O}$ dosimetry, shown at the bottom of Table IV, gives the measured energy deposited by the $0.6-\mathrm{Mev}$ proton released in a thermal neutron field due to the $1.8-\mathrm{b}$ cross section of $\mathrm{N}_{2}$. In this manner, the observed energy deposited is $1.01 \times 10^{21} \mathrm{ev} / \mathrm{g} / \mathrm{hr}\left(16.3 \times 10^{6} \mathrm{rad} / \mathrm{hr}\right)$. A theoretical value of $0.75 \times 10^{21} \mathrm{ev} / \mathrm{g} / \mathrm{hr}$ is obtained by calculation, which is $25 \%$ lower than observed. The range of the proton is $\approx 0.1 \mathrm{~cm}$, in air at atmospheric pressure, (19) and proportionately less at higher pressures. Thus, for a capsule having a diameter of $2.5 \mathrm{~cm}$, the loss of proton energy above 2 atm should be $<4 \%$ of the total proton energy dissipated in the capsule volume, This indicates that the deviation is not entirely due to wall interference.

The pile dosimetry at comparable pressures and geometries can be converted for used in other gaseous systems by considering the radiations as a uniform field. The conversion from $\mathrm{N}_{2} \mathrm{O}$ dosimetry to use for air is as follows:

$n, p+n, y$ energy deposited in $\operatorname{air}\left(4 \mathrm{~N}_{2}+\mathrm{O}_{2}\right)=\left(0.79 \times \frac{44}{29} \times 1.01+0.39\right) \times 10^{21}$

$$
=1.60 \times 10^{21} \mathrm{ev} / \mathrm{g} / \mathrm{hr} \text {. }
$$

This value was used for the $n, p$ and $n, y$ energy developed in nitrogen-oxygen mixtures having compositions of the order of that of air. 
V. Fission Fragment Energy Deposition Efficiency in an oriented Array of U-Glass Fiber.

A general equation for the determination of fission fragment energy deposition efficiency by using an ideal dosimeter is as follows:

$$
\varepsilon=\frac{10^{13} \mathrm{PV}_{\mathrm{g}}[\% \mathrm{C}]}{\mathrm{G} \varphi \mathrm{t} x \mathrm{y}}
$$

where:

$\epsilon \quad=$ fission fragment energy deposition efficiency, express ed as a percent of total fission energy developed in a source which is deposited in the chemical reactant, $\%$ (the equation is based on $170 \mathrm{Mev}$ released per fission event),

$\mathrm{P}=$ pressure of gaseous system, atm,

$\mathrm{V}_{\mathrm{g}}=$ total volume of gas in system, cc,

$[\% \mathrm{c}]=$ concentration by volume of gaseous chemical product formed in dosimeter, \%,

$\mathrm{G}=\mathrm{G}$ value of formation of dosimeter gaseous product, molecules/100 ev,

$\varphi=$ thermal neutron flux, $\mathrm{n} / \mathrm{cm}^{2} / \mathrm{sec}$,

$t=$ time in flux, sec,

$x=$ concentration by weight of $U^{235}$ in fission source, fraction, and

$y=$ weight of fission source exposed to gaseous dosimeter, $g$. Equation (9) is based on a $U^{235}$ fission cross section of 580 b. 
The absorption cross section of $100 \mathrm{~b}$ was neglected in this, since it is estimated that the flux measurement is probably good to only $\pm 15 \%$, and the absorption correction is within this limit. refinement in flux measurements will take the absorption cross section into account.

Unfortunately, the $\mathrm{N}_{2} \mathrm{O}$ dosimeter is non-ideal. Furthermore, the effect of the $n, p$ and $n, \gamma$ energy does not allow the direct use of equation (9). Therefore, the energy deposition was obtained in parts by the subtractive method mentioned above. A series of 18 experiments was carried out for the U glass in a fixed array. The efficiency based on $\mathrm{NO}_{2}, \mathrm{~N}_{2}$, and $\left(\mathrm{N}_{2} \mathrm{O}\right)_{\mathrm{D}}$ was calculated for comparison. Because of the method of analysis, as was discussed above, it was felt that the value based on $\left(\mathrm{N}_{2} \mathrm{O}\right)_{D}$ is the more reliable. The oriented fixed array is closely approximated by a plate-type two-dimensional geometry. Because of the finite holder ring thicknesses (as shown in Figure 3), a fraction. ( 48\%) of the U-glass surface is shielded from the gas. This is taken into account in the calculation. Figure 8 shows the results of the efficiency determinations as a function of U-glass loading in $\mathrm{mg} / \mathrm{cm}^{2}$. The shape of the curve approximates that predicted by geometrical considerations for a two-dimensional element based on fission fragment range data and assuming a thickness equivalent to a foil.

In Table $\mathrm{V}$ a cummary of the $\mathrm{O}_{2} / \mathrm{N}_{2}$ and $\mathrm{NO}_{2} / \mathrm{N}_{2}$ ratios are given, and compared to other work for various types of radiation sources. The $\mathrm{O}_{2}$ and $\mathrm{NO}_{2}$ ratio changes with respect to $\mathrm{N}_{2}$, the former increasing and the latter decreasing slightly as the LET 
increases. These data also indicate the total dose dependence of the $\mathrm{N}_{2}$ yield.

The effect of increasing pressure for a U-glass fixed array at a loading of $1.67 \mathrm{mg} / \mathrm{cm}^{2}$ is given in Figure 9. The data indicate that there is a pressure dependence of efficiency. Since it has been shown that the $\mathrm{N}_{2} \mathrm{O}$ dosimeter is pressure independent, the conclusion is that there must be a geometric effect which is due to the interference of the walls of the vessel with the fission fragment range. The range of the fission fragment varies inversely with pressure as given by the following approximation: (19)

$$
R_{m}=R_{0}\left(\rho_{o} / \rho_{m}\right)\left(A_{m} / A_{0}\right)^{\frac{1}{2}}
$$

where:

$R$ = the average range of the average fission fragment in the stopping medium, $\mu$,

$\rho=$ density of the medium, $\mathrm{g} / \mathrm{cc}$, and

A = atomic weight of medium, on a per atom basis.

The subscript:m = unknown medium, and the subscript $0=$ known medium.

The fission fragment range in air at 1 atm and ambient temperature is $2.2 \mathrm{~cm}$, and that of $\mathrm{N}_{2} \mathrm{O}, 1.47 \mathrm{~cm}$. At 3 atm for $\mathrm{N}_{2} \mathrm{O}$ the range is thus $0.5 \mathrm{~cm}$, and at $20 \mathrm{~atm}, 0.07 \mathrm{~cm}$. The walls of the vessel could then interfere with the fission fragment range at 3 atm pressure. From Figure 9 it can be seen that, above $\approx 20 \mathrm{~atm}$ pressure, the wall effect is neyligible. The total etticiency of 
the fixed.array of fibers at a pressure of 1.6 to 4.6 atm (Figure 8) should be multiplied by an average factor of $33 \% / 21 \%=1.57$ for determining the total unperturbed efficiency. This wall factor is not unreasonable from geometrical considerations. The upper broken line in Figure 8 indicates the unperturbed efficiency.

VI. Fission Fragment Energy Deposition Efficiency of a Random Packing of Glass Wool.

Table VI gives the experimental and calculated values $(20)$ for a random packing of glass wool in two runs. The experimental values are in disagreement with the calculated values for two reasons: (1) the wall effect at 3.3 to $3.7 \mathrm{~atm}$, and (2) the probable non-homogeneity of the fiber and the packing.

VII. Fission Fragment Energy Deposition Efficiency of Metal Foils. The experimentally observed deposition efficiencies for the $27.6 \% \mathrm{U}-\mathrm{Al}$ foils and the $18.3 \% \mathrm{U}-\mathrm{Pd}$ foils were made in a series of 9 and 5 runs, respectively, at pressures ranging from 2.4 to 4.5 atm. Five experiments were also made over a range of pressures from 2.4 to $40.0 \mathrm{~atm}$. The data are summarized in Table VII. The efficiency, as a function of pressure for the U-Pd foil, is plotted in Figure 9 (broken line). The wall loss effect is not as large as in the case of the oriented glass fiber, because of the better triangular geometry of the fission source with respect to the cylindrisal walls of the vessel. The average wall factor is 1.2 . All the efficiency information for lhe foils is plotted in Figure 10 
as a function of foil thickness to range ratio ( $t / R)$, by using a range estimated from equation (10) of $6.1 \mathrm{H}$ for the U-Pd alloy, and a reference range of $13.7 \mu$ for $\mathrm{Al} .(21)$ The various curves are based on geometric calculations, various modes of energy loss, and $G$ value variations as described previously. $(1,22)$

For infinite plate.linear energy deposition,

$$
\begin{gathered}
E=E_{0}(1-r / R), \\
\varepsilon / 100=1-3 / 4(t / R)+1 / 2(t / R) \ln (t / R) ; \text { for } t \leq R,
\end{gathered}
$$

and

$$
\varepsilon / 100=1 / 4 /(t / R) ; \text { for } t \geq R \text {. }
$$

For infinite plate quadratic energy deposition,

$$
\begin{gathered}
E=E_{0}(1-r / R)^{2} \\
\epsilon / 100=1-1 / 2(t / R)-1 / 3(t / R)^{2}+(t / R) \ln (t / R) ; \text { for } t \leq R, \\
\epsilon / 100=1 / 6 /(t / R) ; \text { for } t \geq R .
\end{gathered}
$$

and

where:

$t=$ thickness of plate, $\mu$, and

$r=$ distance along fission fragment track, $\mu$.

The data fall mainly around the curves for a linear energy loss a 1 quadratic energy loss at a constant $G$ value along the track. The data thus indicate that there is no tendency for the G value to increase along the length of the track, in agreement with the finding of the independence of the $\mathrm{N}_{2} \mathrm{O}$ dosimeter from LET effect. (3) Furthermore, by assuming that the dosimeter is independent of LET, the range used in calculating the efficiency by the above equations is reasonably correct. 
In the case of the thick U-Al foils (above 2 range thicknesses), the efficiency of a group of 5 experiments tends to fall higher than predicted. This may be due to increasing inaccuracies in the analysis of smaller concentrations in the $\mathrm{N}_{2} \mathrm{O}$ dosimeter, although secondary energy transfer effects cannot be ruled out. Unfortunately, the data are not precise enough to indicate which of the two modes of energy deposition, given by equations (11) and (14), is preferable in making geometric calculations of efficiency for thicknesses below 2 fission fragment ranges. A summary for maximum efficiencies found in this work, observed and corrected for wall interferences, is given in Table VIII.

VIII. Co ${ }^{60}$ Gamma Irradiation of $77 \% \mathrm{~N}_{2}+23 \% \mathrm{O}_{2}$ Gas. The $\mathrm{N}_{2}+\mathrm{O}_{2}$ mixture was irradiated in the co ${ }^{60}$ gamma field in $\mathrm{Al}$ vessels over a range of pressures of 7.9 to $73 \mathrm{~atm}$. The G values for $\mathrm{NO}_{2}$ formation are plotted in Figure 11, range from 0.81 to 0.64 as pressure increases, and for $\mathrm{N}_{2} \mathrm{O}$ in Figure 12, the $\mathrm{G}$ values range from 0.09 to 0.15 . The trends in value do not appear significant. The maximum concentration of $\mathrm{NO}_{2}$ in this series of experiments was $0.21 \%$ reflecting the low dose rate used $\left(0.057 \times 10^{21}\right.$ $\mathrm{ev} / \mathrm{g} / \mathrm{hr})$. It is significant that the $\mathrm{G}\left(\mathrm{N}_{2} \mathrm{O}\right)$ values are relatively low, and thus the ratios of $\mathrm{NO}_{2} / \mathrm{N}_{2} \mathrm{O}$ high (ranging from 3.4 up to as high as 9.3).

IX. Pile Irradiation of $77 \% \mathrm{~N}_{2}+23 \% \mathrm{O}_{2}$ Gas. The $\mathrm{N}_{2}+\mathrm{O}_{2}$ gas mixture was irradiated in both $\mathrm{Al}$ and 
quartz capsules in the pile. The $G$ value data are presented in Figures 11 and 12 , together with the co ${ }^{60}$ data. The equivalent dose rate of $n, p$ and $n, \gamma$ pile radiation was $1.60 \times 10^{21} \mathrm{ev} / \mathrm{g} / \mathrm{hr}$, which is 28 times the dose rate. in the gamma field. The $\mathrm{G}\left(\mathrm{NO}_{2}\right)$ values follow approximately the same decreasing trend with pressure; they lie slightly higher than the gamma values, and range from 0.57 to 0.83 with one high value of 1.5. The $\mathrm{G}\left(\mathrm{N}_{2} \mathrm{O}\right)$ values are significantly higher ( 3 to 5 times) in the pile than in the gamma field. The $\mathrm{G}\left(\mathrm{N}_{2} \mathrm{O}\right)$ values tend to first decrease from 0.5 in the range of 0.6 to $6.0 \mathrm{~atm}$ to about 0.3 at $18 \mathrm{~atm}$, and thereafter level off up to a pressure of $73 \mathrm{~atm}$. The difference in the $\mathrm{N}_{2} \mathrm{O}$ yield from gamma pile radiation may be due to secondary kinetic effects. The $\mathrm{NO}_{2} / \mathrm{N}_{2} \mathrm{O}$ ratio varies from 1.1 to 2.9 and the $\mathrm{NO}_{2}$ concentration ranges up to as high as $9.8 \%$.

X. Fission Fragment Irradiation of $77 \% \mathrm{~N}_{2}+23 \% \mathrm{O}_{2}$ Gas With U-Containing Glass Fiber:

For the determination of $G$ values due to fission fragments, the quantity of $\mathrm{NO}_{2}$ and $\mathrm{N}_{2} \mathrm{O}$ formed due to the pile $(\mathrm{n}, \mathrm{p}$ and $n, \gamma)$ radiation are subtracted from the total concentrations using $\mathrm{G}\left(\mathrm{NO}_{2}\right)=$ 0.90 and $\mathrm{C}\left(\mathrm{N}_{2} \mathrm{O}\right)=0.55$. The eneryy deposited is based on $\mathrm{N}_{2} \mathrm{O}$ dosimetry at a pressure 0.66 times that of the $77 \% \mathrm{~N}_{2}+23 \% \mathrm{O}_{2}$ pressure. In Table IX, the experimental concentrations and calculated fission fragment $G$ values are presented. Although there is a decided scatter of the data, the $\mathrm{G}\left(\mathrm{NO}_{2}\right)$, values in the pressure range 2.5 to $3.8 \mathrm{~atm}$ vary between 0.7 and 1.7 , and the $\mathrm{G}\left(\mathrm{N}_{2} \mathrm{O}\right)$ values 
range from 0.70 to 2.1 . Two runs at 47.6 and 68 atm gave $\mathrm{G}\left(\mathrm{NO}_{2}\right)$ values of 0.5 and 1.0 respectively, and $G\left(\mathrm{~N}_{2} \mathrm{O}\right)$ values of 0.9 and 1.4 . A difficulty at high pressure for a given mass of $U$ is that the pile radiation background correction becomes significant and the probability of error in determining fission fragment energy by difference becomes greater.

$\mathrm{XI}$. Fission Fragment Irradiation of $77 \% \mathrm{~N}_{2}+23 \% \mathrm{O}_{2}$ Gas With U-Al Foils of Varying Thickness.

Figure 13 illustrates the fission fragment $G$ values for $\mathrm{NO}_{2}$ and $\mathrm{N}_{2} \mathrm{O}$ as a function of foil thickness in terms of the number of fission fragment ranges in $A l(t / R)$. The $G$ values tend to decrease with increasing thickness, which seems contrary to the findings of Edwards and Moseley (26) that the energy at the end of the fission fragment track is more effective in forming $\mathrm{NO}_{2}$ than at the beginning. of the track. Actually, beyond a thickness of $t / R=1$, the average fission fragment energy does not change; however, the $\mathrm{G}\left(\mathrm{NO}_{2}\right)$ values of the three points at $t / R \cong 0.5$ are consistently higher $(0.76$ to 0.93$)$ than the three points at a $t / R>1.0(0.46$ to 0.62$)$. The same can be said for the $\mathrm{G}\left(\mathrm{N}_{2} \mathrm{O}\right)$ value. The average energy of the fission fragment energing from foils, assuming linear energy loss, is 0.5 of the initial energy at $t / R=0.5$ and it is 0.24 at $t / R \geq 1$.

XII. Fission Fragment Irradiation of $77 \% \mathrm{~N}_{2}+23 \% \mathrm{O}_{2}$ Gas With U-Containing Metal Foil, clad with U-Free Metal Foil. Another attempt at determining $G$ formation values as a 
function of residual range was made by the irradiation of the $\mathrm{N}_{2}+\mathrm{O}_{2}$ gas with one thickness of foil source, and placing increasing thicknesses of U-free metal foil cladding on both sides of the fission source foil. Table $\mathrm{X}$ gives the observed fission fragment energy deposition efficiency for $A l$ and Pd cladding of U-Al and U-Pd alloys, respectively. As noted previously, the U-Pd deposition efficiency decreases normally to low values as the range of the fragment is exceeded by the cladding thickness; however, in the case of the U-Al foils, the efficiency seems to level off at 8 to $10 \%$. Further investigation is needed to confirm this effect.

Figure 14 shows the $\mathrm{G}\left(\mathrm{NO}_{2}\right)$ value for the two sets of foils as a function of cladding thickness. Admittedly, there is a paucity of data; however, the three sets of points are consistent and show a progression from 0.74 to 0.94 with a 2.5 -fold increase in cladding thickness. The increase in $G\left(\mathrm{~N}_{2} \mathrm{O}\right)$ is from 0.52 to 0.65 for a fourfold increase in Pd cladding thickness. This $25 \%$ increase in G values, however, does not support the order of magnitude increase indicated in a previous study ${ }^{(26)}$ on the effect of track distance on the G value.

XII. Summary of $\mathrm{G}\left(\mathrm{NO}_{2}\right)$ and, $\mathrm{G}\left(\mathrm{N}_{2} \mathrm{O}\right)$ Values.

A summary of the $\mathrm{NO}_{2}$ and $\mathrm{N}_{2} \mathrm{O}$ yields is given in Table $\mathrm{XI}$, together with yields from other sources. It is apparent. from this work, at $25^{\circ} \mathrm{C}$ and in the range of 0.6 to $73 \mathrm{~atm}$ pressure, that the $\mathrm{G}\left(\mathrm{NO}_{2}\right)$ does not appear to increase significantly with radiation intensity, but that $\mathrm{G}\left(\mathrm{N}_{2} \mathrm{O}\right)$ has an increasing trend. The wider scatter in the case of the fission fragments reflects the difficulty 
of determining $G$ values with this type of radiation. The yield data are in reasonable agreement with other lower pressure determinations, but do not seem to agree with the higher pressure $\mathrm{G}\left(\mathrm{NO}_{2}\right)$ values which reach a value as high as 5.6. The fission fragment $\mathrm{G}\left(\mathrm{NO}_{2}\right)$ values at higher temperatures, from literature data at $200^{\circ}$ to $250^{\circ} \mathrm{C}$, are not in agreement with each other, possibly because of different types of sources used. This work together with the literature data seem to indicate an increasing trend with temperature; however, further study is needed.

\section{Conclusions}

The nitrous oxide gas dosimeter is satisfactory for work in a co ${ }^{60}$ gamma radiation field provided proper precautions are taken in calibration. It has been found to be independent of . pressure up to $37 \mathrm{~atm}$. The $\mathrm{N}_{2}, \mathrm{O}_{2}$, and $\mathrm{N}_{2} \mathrm{O}$ decomposition yields have been found to be dose dependent. The $\mathrm{N}_{2} \mathrm{O}$ dosimeter can be used with proper care for determination of the fission fragment energy deposition efficiency of U-containing sources. Its most serious drawback is the neutron absorption reaction due to the relatively high cross section of nitrogen.

Thin fission sources can be constructed to yield over $50 \%$ energy deposition efficiency. Deposition efficiencies calculated from fission fragment range data and geometric considerations are in approximate agreement with observed values using the $\mathrm{N}_{2} \mathrm{O}$ dosimeter. Further work is needed for establishing either the linear 
or the quadratic energy deposition models for predicting efficiencies. The yield of $\mathrm{NO}_{2}$ and $\mathrm{N}_{2} \mathrm{O}$ formation from an air mixture; with varying foil thicknesses and foil cladding, do not support the view that the $G$ values increase along the length of the fission fragment track. The results of this work do not show any significant increase in $\mathrm{G}\left(\mathrm{NO}_{2}\right)$ values with pressure at $25^{\circ} \mathrm{C}$. Further work is needed both in static and in flowing systems for determining the fission fragment $G$ formation values as a function of pressure and temperature.

Acknowledgment

The authors acknowledge with appreciation the aid of J. J. Floyd, F. P. Reeve, A. Banslaben, and W. D. Tucker in arranging for the irradiations at the Brookhaven Graphite Research Reactor and for construction of the laboratory equipment; the aid of S. J. Tassinari and J. Forrest of the Radiochemical Analysis Group of the Nuclear Engineering Department, for performing the wet chemical and mass spectrometric analyses, and the aid of Mr. G. Farber for fabrication of the fission source elements. 


\section{REFERENCES}

1. M. Steinberg, Chemonuclear reactors and chemical processing, in "Advances in Nuclear Science and Technology," Vol. I, pp. 247-333, edited by E. J. Henley and H. Kouts, Academic Press, Nèw. York \& Ioòndon, 1962.

2. P. Harteck and S. Dondes, Nucleonics 14, 66-72 (1956).

3. J. A. Hearne and R. W. Hummel, Radiation Research 15, 254-67 (1961).

4. D. A. Flory and W. R. McIntosh, U. S. Air Force, ANP Doc. No. 60-34T, FZ-K9-182 (1961).

5. F. Moseley and A. E. Truswell, Atomic Energy Research Establishment, AERE-R 3078 (1960).

6. American Society for Testing Materials, D 1671-59T, Philadelphia (1959).

7. G. R. A. Johnson, J. Inorg. Nuclear Chem. 24, 461-68 (1962).

8. D. A. Landsman, private communication, Atomic Energy Research Establishment, Harwell (1962).

9. R. Gorden, Jr. and P. J. Ausloos, "The Radiolysis of Nitrous Oxide", preliminary report, National Bureau of Standards, Washington, D. C. (1962).

10. A. D. Kolumbon and H. Essex, J. Chem. Phys. 8, 450-4 (1940).

11. M. T. Dmitriev and L. V. Saradzhev, Russian J. Phys. Chem. 35 , No. 4, 354-9 (1961).

12. M. Steinberg, Brookhaven National Laboratory, BNL 612 (T-182); 1960 .

13. R. A. Anderson, J. V. Best, and D. A. Dominey, J. Chem. Soc. $1962,3498-3503$.

14. P. Harteck and S. Dondes, Nucleonics 14, 22-5 (1956).

15: J. J. Floy, and H. Goland, private communication, Brookhaven National Laboratory (1962).

16. S. Glasstone, "Textbook of Physical Chemistry;"! pp. 836-7, Van Nostrand, New York, 1946.

17. S. Glasstone, "Principles of Nuclear Reactor Engineering;" Van Nostrand, New York, 1955. 
18. American Society for Testing Materials, Special Technical Bulletin 148 D, Philadelphia (1959).

19. R. D. Evans, "The Atomic Nucleus," pp. 649-53 and pp. 668-71, McGraw Hil1, New York, 1955.

20. M. Steinberg, J. R. Powell, and L. Green, Brookhaven National Laboratory, BNL $602(\mathrm{~T}-175), 1961$.

21. E. Segre and C. Wiegand, Phys. Rev. 70, 808-11 (1959).

22. J. Sears and M. Steinberg, Brookhaven National Laboratory, BNL 695. (T-238), 1961 .

23. M. T. Dmitriev and S. Ya Pshezhetskii, Russian J. Phys. Chem. 35, No. 5, 495-9 (1961).

24. M. T. Dmitriev and J. Ya Pshezhetskii, Russian.J. Phys. Chem. 34, No. 4, 418-21 (1960).

25. F. Moseley, A. E. Truswell, and C. G. Edwards, Atomic Energy Research Establishment,. AERE-M 564 (1959).

26. C. G. Edwards and F. Moseley, Atomic Energy Research Establishment, AERE C.C/R. 2710 (1958).

27. Aerojet-General Nucleonics, AGN 3048, California (1959).

28. S. C. Lind, "Radiation Chemistry of Gases," pp. 232-45, 282, Reinhold Publishing Co., New York, 1961. 


\section{List of Tables}

Table I

Table II

Table III

Table IV

Table V

Table VI

Table VII

Table VIII

Table IX

Table $\mathrm{x}$

Table XI
Fission Fragment Sources. Calibration of $\mathrm{N}_{2} \mathrm{O}$ Dosimeter with $\mathrm{Co}^{60}$ Gamma
Radiation.

Pile Radiation Dosimetry with $\mathrm{N}_{2} \mathrm{O}$. Gas.

Pile Radiation Dosimetry with $\mathrm{CO}_{2}$ Gas.

$\mathrm{N}_{2} \mathrm{O}$ Dosimetry - Summary of Composition Ratios.

Fission Fragment Energy Deposition Efficiency of a Random Packing of U-Glass Wool.

Fission Fragment Energy Deposition Efficiency of UContaining Metal Foils.

Maximum Efficiency of Fission Fragment Energy Deposition Observed in This study.

Fission Fragment Irradiation of $77 \% \mathrm{~N}_{2}+23 \% \mathrm{O}_{2}$ Gas Fixed Array of U-Glass Fiber.

Fission Fragment Energy Deposition Efficiency of UContaining Metal Foil Clad with U-Free Foil.

Summary of $\mathrm{NO}_{2}$ and $\mathrm{N}_{2} \mathrm{O}$ Yields for $75 \%$ to $80 \% \mathrm{~N}_{2}$ and $20 \%$ to $25 \% \mathrm{O}_{2}$ Gas Mixtures. 


\section{List of Figures}

Figure 1

Figure 2

Figure 3

Figure 4

Figure 5

Figure 6

Figure 7

Figure 8

Figure 9

Figure 10

Figure 11

Fiqure 12
Quartz Break Seal Irradiation Vessel. containing glaiss wool fission source. containing metal foil fission source.

Left: URight: U-

Aluminum Irradiation Pressure Vessel. U-containing glass fiber fission source in an oriented array shown inside the vessel.

U-containing Fission Source Discs. Bight: U-Al foil $0.5 \mathrm{mil}$ thick containing $25.8 \mathrm{w} / \mathrm{O} \mathrm{U}^{23}$. Left: Uglass fibe $335^{\text {in }}$ an oriented fixed array containing $36.8 \mathrm{w} / \mathrm{O} \mathrm{U}^{235}$.

Vacuum Rack. On rack from left to right - (1) Al pressure container in filling position, (2). expansion bullo for high pressure runs, (3) glass vessel containing break seal quartz capsule, (4) Al pressure container with transfer trap, (5) Alphatron gauge and recorder, and (6) Wallace \& Tiernan Bourdon gauge.

Calibration of $\mathrm{N}_{2} \mathrm{O}$ Dosimeter $-\mathrm{NO}_{2}$. formation vs total dose. Calibration of $\mathrm{N}_{2} \mathrm{O}$ Dosimeter $-\mathrm{N}_{2}$ formation vs total
dose.

Calibration of $\mathrm{N}_{2} \mathrm{O}$ Dosimeter $-\mathrm{N}_{2} \mathrm{O}$ decomposed vs total dose.

Fission Fragment Energy Deposition Efficiency as a function of $\mathrm{U}^{235}$ weight loading for an oriented fixed array of strands of 5 twisted $3 \mu$ U-glass fiber.

Fission Fragment Energy Deposition Efficiency vs pressure.

Relative Fission Fragment Efficiency for Slabs vs Thickness to Range Ratio.

$\mathrm{Co}^{60}$ and Pile Radiation of $77 \% \mathrm{~N}_{2}$ and $23 \% \mathrm{O}_{2}$ Mixture $\mathrm{G}\left(\mathrm{NO}_{2}\right)$ Value vs Filling Pressure.

$\mathrm{Co}^{60}$ and Pile Radiation of $77 \% \mathrm{~N}_{2}$ and $23 \% \mathrm{O}_{2}$ Mixture $\mathrm{G}\left(\mathrm{N}_{2} \mathrm{O}\right)$ Value vs Filling Pressure. 
Figure 13 . Fission Fragment Irradiation of $77 \% \mathrm{~N}_{2}$ and $23 \% \mathrm{O}_{2}$ Mixture - $\mathrm{G}\left(\mathrm{NO}_{2}\right)$ and $\mathrm{G}\left(\mathrm{N}_{2} \mathrm{O}\right)$ Values vs Foil Thickness.

Figure 14 Fission Fragment Irradiation of $77 \% \mathrm{~N}_{2}$ and $23 \% \mathrm{O}_{2}$ Mixture - $\mathrm{G}\left(\mathrm{NO}_{2}\right)$ Value vs Foil clad Thickness. 
TABLE I

$\mathrm{U}^{235}$ CONTAINING FISSION FRAGMENT SOURCES

\begin{tabular}{|c|c|c|c|c|c|}
\hline $\begin{array}{l}\text { Fission Fragment } \\
\text { Source } \\
\text { and Dimensions }\end{array}$ & $\begin{array}{l}\text { Composition } \\
\text { by Weight } \\
\text { anc } \mathrm{U}^{235} \text { Content }\end{array}$ & $\begin{array}{l}\text { Softening } \\
\text { Point } \\
{ }^{\circ} \mathrm{C} \\
\end{array}$ & Density & $\begin{array}{l}\text { Average } \\
\text { F.F: Range } \\
\mu\end{array}$ & Supplier \\
\hline $\begin{array}{l}\text { 1. Glass Fiber } \\
\text { Five } 3 \mu \text { filaments } \\
\text { twisted into one } \\
\text { strand }\end{array}$ & $\begin{array}{r}50 \% \mathrm{U}_{3} \mathrm{O}_{8} \\
40 \% \mathrm{SiO}_{2} \\
10 \% \mathrm{Na}_{2} \mathrm{O} \\
\left(36.8 \% \mathrm{U}^{235}\right) \\
\end{array}$ & 700 & 3.66 & 13.7 & $\begin{array}{l}\text { Owens-Corning Fiberglas } \\
\text { Co., Granville, Ohio. }\end{array}$ \\
\hline 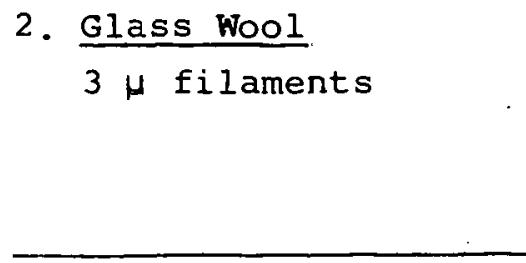 & $\begin{array}{r}50 \% \mathrm{U}_{3} \mathrm{O}_{8} \\
40 \% \mathrm{SiO}_{2} \\
10 \% \mathrm{Na}_{2} \mathrm{O} \\
\left(36.8 \% \mathrm{U}^{235}\right) \\
\end{array}$ & 700 & 3.66 & 13.7 & $\begin{array}{l}\text { Owens-Corning Fiberglas } \\
\text { Co.., Granville, Ohio }\end{array}$ \\
\hline $\begin{array}{l}\text { 3. U-Al Alloy } \\
\text { Metal Foil } \\
\text { Thickness varying } \\
\text { from } 6 \mu \text { to } 13 \mu\end{array}$ & $\begin{array}{c}27.6 \% \mathrm{U} \\
72.4 \% \mathrm{Al} \\
\left(25.8 \% \mathrm{U}^{235}\right)\end{array}$ & 730 & 3.47 & 13.7 & $\begin{array}{l}\text { Sylvania Electric Pro- } \\
\text { ducts Co.. Bayside, N.Y. }\end{array}$ \\
\hline $\begin{array}{l}\text { 4. U-Pd Alloy Metal } \\
\text { Foil } \\
\text { Thickness varying } \\
\text { from } 1.5 \mu \text { to } 13 \mu\end{array}$ & $\begin{array}{r}-8.2 \% \mathrm{U} \\
81.8 \% \mathrm{Pd} \\
\left(17.0 \% \mathrm{U}^{235}\right) \\
\end{array}$ & 1400 & 12.75 & 6.1 & $\begin{array}{l}\text { BNL and Arnold Engineer- } \\
\text { ing Co. Marengo, } \\
\text { Illinois }\end{array}$ \\
\hline
\end{tabular}


TABLE II

CALIBRATION OF $\mathrm{N}_{2}$ O DOSIMETER WITH CO ${ }^{60}$ GAMMA RADiATION

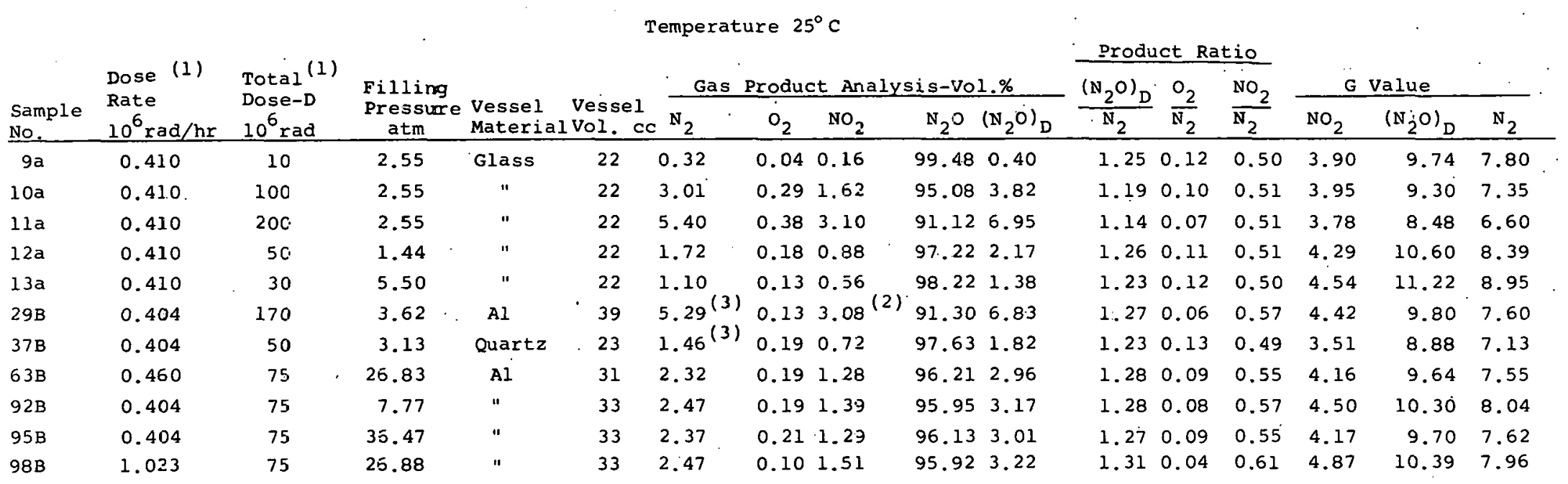

(1) Absorbed dose in $\dot{N}_{2} \mathrm{O}=10.9$ of dose indicated by Fricke Dosimeter $\mathrm{D}$, shown in Table. Shielding due to aluminam vessel results in dose rate $=0.35$ of dose indicated by Fricke Dosimeter.

(2) Washing of Al container indicated $18 \% \mathrm{NO}_{2}$ condensed on Al included in analysis.

(3) Nitrogen analyzed on gas chromatograph confirmed calculated value. 
TABLE III

PILE RADIATION DOSIMETRY WTTH $\mathrm{N}_{2} \mathrm{O}$ GAS

$(n, y)$ Pile and $(n, p)$ Radiation - Temperature $25-30^{\circ} \mathrm{C}$

\begin{tabular}{|c|c|c|c|c|c|c|c|c|c|c|c|c|c|c|c|c|}
\hline \multirow[b]{2}{*}{$\begin{array}{l}\text { Sample } \\
\text { No. }\end{array}$} & \multirow[b]{2}{*}{$\begin{array}{l}\text { Filling } \\
\text { Pres- } \\
\text { sure } \\
\text { atm } \\
\end{array}$} & \multirow[b]{2}{*}{$\begin{array}{c}\text { Wt of } \\
\text { Gas } \\
\text { g }\end{array}$} & \multirow[b]{2}{*}{$\begin{array}{l}\text { Time } \\
\text { In-pile } \\
10^{3} \text { sec }\end{array}$} & \multirow[b]{2}{*}{$\begin{array}{c}\begin{array}{c}\text { Thermal } \\
\mathrm{n}-\mathrm{flux}\end{array} \\
10^{12} \mathrm{n} / \mathrm{cm}^{2} / \mathrm{sec}\end{array}$} & \multirow{2}{*}{\multicolumn{2}{|c|}{ Gas Product }} & \multicolumn{2}{|c|}{ Analysis - } & \multirow[b]{2}{*}{$\frac{\text { Vol. } \%}{\left(\mathrm{~N}_{2} \mathrm{O}\right)_{D}}$} & \multicolumn{3}{|c|}{ Product Ratio } & \multirow[b]{2}{*}{$\begin{array}{l}\text { Energy } \\
\mathrm{E}\left(\mathrm{NO}_{2}\right) \\
\end{array}$} & & & \multirow[b]{2}{*}{$\begin{array}{l}\text { Dose Rate } \\
10^{6} \mathrm{rad} / \mathrm{hr}\end{array}$} \\
\hline & & & & & & & $\begin{array}{c}\text { Anal } \\
\mathrm{O}_{2}\end{array}$ & $\frac{\mathrm{sis}-}{\mathrm{N}_{2} \mathrm{C}}$ & & $\frac{\left(\mathrm{N}_{2}{ }^{\mathrm{O}}\right)_{\mathrm{D}}}{\mathrm{N}_{2}}$ & $\frac{\mathrm{O}_{2}}{\mathrm{~N}_{2}}$ & $\frac{\mathrm{NO}_{2}}{\mathrm{~N}_{2}}$ & & $\begin{array}{r}\text { Output } \\
E\left(\mathrm{~N}_{2}\right)\end{array}$ & $\frac{10^{21} \mathrm{ev}}{\mathrm{E}\left(\mathrm{N}_{2} \mathrm{O}\right)_{\mathrm{D}}}$ & \\
\hline 1 & 2.7 & 0.120 & 86.4 & 7 & 8.54 & 14.37 & 0.77 & 76.32 & 17.90 & 1.25 & 0.05 & 0.59 & 3.90 & 3.25 & 3.23 & 18.0 \\
\hline 2 & 2.5 & 0.110 & 57.6 & 7 & 5.11 & 9.89 & 1.12 & 83.88 & 12.44 & 1.26 & 0.11 & 0.52 & 2.13 & 2.00 & 2.02 & 18.4 \\
\hline 3 & 2.3 & 0.100 & 36.0 & 7 & 4.60 & 7.72 & 0.41 & 87.27 & 11.90 & 1.54 & 0.05 & 0.59 & 1.75 & 1.40 & 1.77 & 28.3 \\
\hline 4 & 3.0 & 0.098 & 36.0 & 5.9 & 3.12 & 7.04 & 2.58 & 87.26 & 7.67 & 1.09 & 0.37 & 0.44 & 1.16 & 1.24 & 1.10 & 18.0 \\
\hline 5 & 2.8 & 0.142 & 25.2 & 7 & 2.77 & 6.38 & 1.11 & 89.74 & 7.76 & 1.22 & 0.17 & 0.43 & 1.49 & 1.62 & 1.60 & 25.7 \\
\hline 6 & 3.0 & 0.130 & 18.0 & 7 . & 2.17 & 4.43 & 0.59 & 92.81 & 5.52 & 1.25 & 0.13 & 0.50 & 1.07 & 1.01 & 1.03 & 25.4 \\
\hline 7 & 3.0 & 0.116 & 18.0 & 7 & 2.09 & 4.31 & 0.58 & 93.02 & 5.36 & 1.24 & 0.13 & 0.49 & 0.92 & 0.88 & 0.89 & 24.4 \\
\hline 8 & 1.8 & 0.088 & 3.6 & 6.6 & 0.38 & 0.90 & 0.11 & 98.61 & 1.05 & 1.17 & 0.12 & 0.42 & 0.13 & 0.12 & 0.12 & 21.8 \\
\hline 9 & 2.9 & 0.119 & 24.6 & 6.6 & 2.82 & 5.58 & 0.68 & 90.92 & 6.99 & 1.25 & 0.12 & 0.50 & 1.28 & 1.18 & 1.20 & 23.7 \\
\hline $62 B$ & 2.5 & 0.143 & 3.6 & 6.6 & 0.28 & 0.65 & 0.17 & 98.62 & 1.01 & 1.16 & 0.26 & 0.41 & 0.15 & 0.14 & 0.19 & 21.2 \\
\hline
\end{tabular}


TABLE IV

PILE RADIATION DOSIMETRY WITH $\mathrm{CO}_{2}$ GAS (CONTAINING $0.5 \% \mathrm{NO}_{2}$ )

$(n, y)$ Pile Radiation - Temperature $25-30^{\circ} \mathrm{C}$

\begin{tabular}{|c|c|c|c|c|c|c|c|c|c|c|c|}
\hline \multirow[b]{2}{*}{$\begin{array}{l}\text { Sample, } \\
\text { No. }\end{array}$} & \multirow{2}{*}{$\begin{array}{l}\text { Filling } \\
\text { Pres- } \\
\text { sure } \\
\text { atm } \\
\end{array}$} & \multirow[b]{2}{*}{$\begin{array}{c}\text { Wt of } \\
\text { Gas } \\
\text { g }\end{array}$} & \multirow{2}{*}{$\begin{array}{l}\text { Time } \\
\text { In-pile } \\
10^{3} \text { sec }\end{array}$} & \multirow{2}{*}{\multicolumn{2}{|c|}{$\begin{array}{l}\text { Thermal } \\
\text { flux } \\
10^{12} \mathrm{n} / \mathrm{cm}^{2} / \mathrm{sec}\end{array}$}} & \multirow{2}{*}{$\begin{array}{l}\text { In- } \\
\text { ibitor } \\
\mathrm{NO}_{2} \\
\mathrm{Vol}^{2} \%\end{array}$} & \multicolumn{3}{|c|}{$\begin{array}{l}\text { Gas Product } \\
\text { Analysis }\end{array}$} & \multicolumn{2}{|c|}{ Energy output } \\
\hline & & & & & & & $\begin{array}{l}\mathrm{CO}_{2} \\
\mathrm{Vol} \% \\
\end{array}$ & $\begin{array}{l}\mathrm{CO} \\
\mathrm{Vol} \%\end{array}$ & $\begin{array}{c}\mathrm{O}_{2} \\
\mathrm{Vol} \% \\
\end{array}$ & $10^{21} \mathrm{ev}^{(1)}$ & $10^{6} \mathrm{rad} / \mathrm{hr}$ \\
\hline 101 & 1.96 & 0.072 & $37 \% 6$ & & 7 & 0.43 & 98.00 & 1.13 & 0.44 & 0.31 & 6.52 \\
\hline 102 & 3.20 & 0.275 & 79.2 & & 7 & 0.5 & 96.26 & 2.19 & 1.02 & 2.20 & $5 . \dot{8} 0$ \\
\hline
\end{tabular}

1) Based on $G(C O)=3.70 ; \cdot e v=3.70 \times 10^{21} \mathrm{wg}_{\mathrm{g}}[\% \mathrm{CO}]$

Pile Radiation $\mathrm{N}_{2} \mathrm{O}$ Dosimetry $\mathrm{n}, \mathrm{y}+\mathrm{n}, \mathrm{p} \quad 22.49 \times 10^{6} \mathrm{rad} / \mathrm{hr}=1.40 \times 10^{21} \mathrm{ev} / \mathrm{g} / \mathrm{hr}$

Pile Radiation $\mathrm{CO}_{2}$ Dosimetry $\mathrm{n}, \mathrm{Y}$

$6.15 \times 10^{6} \mathrm{rac} / \mathrm{hr}=0.39 \times 10^{21} \mathrm{ev} / \mathrm{g} / \mathrm{hr}$

$\mathrm{N}^{14}(\mathrm{n}, \mathrm{p}) \mathrm{C}^{14}$. Radiation $\quad 16.33 \times 10^{6} \mathrm{rad} / \mathrm{hr}=1.01 \times 10^{21} \mathrm{ev} / \mathrm{g} / \mathrm{hr}$

From calculation of $\mathrm{n}, \mathrm{p}$ crcss section $=1.8 \mathrm{~b}$ and $0.5 \mathrm{Mev}=12.0 \times 10^{6} \mathrm{rad} / \mathrm{hr}=0.75 \times 10^{21} \mathrm{ev} / \mathrm{g} / \mathrm{hr}$

Converting $\mathrm{N}_{2} \mathrm{O}$ dosimetry for air $\left(4 \mathrm{~N}_{2}+\mathrm{O}_{2}\right)=\left(0.79 \times \frac{44}{29} \times 1.01+0.39\right) \times 10^{21}=1.60 \times 10^{21} \mathrm{ev} / \mathrm{g} / \mathrm{hr}$ 


\section{TABLE V \\ $\mathrm{N}_{2} \mathrm{O}$ DOSIMETRY \\ Summary of Composition Ratios}

Type of Radiation

This work

Co $^{60}$ Gamma
Pile $(n, p+n, y)$
Fission Source \& Pile.

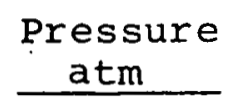

1. $4-40.0$

$1.8-3.0$

$1.6-4.6$

$3.5-37.4$

Other Work Reported.

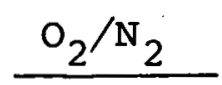

$\mathrm{NO}_{2} / \mathrm{N}_{2}$

0.52

0.15

0.49

0.18

0.42

0.15

0.46

$\begin{array}{lll} & 0.14 & 0.48 \\ 0.4-35.0 & 0.06-0.16 & 0.4-0.6\end{array}$


TABLE VI

FISSION FRAGMENT ENERGY DEPOSITION EFFICIENCY

RANDOM PACKING OF U-GLASS WOOL, $\mathrm{N}_{2} \mathrm{O}$.DOSIMETRY

Temperature $-25^{\circ} \mathrm{C}$

Time In-pile $3,600 \mathrm{sec}$

Flux $-7 \times 10^{12} \mathrm{n} / \mathrm{cm}^{2} / \mathrm{sec}$

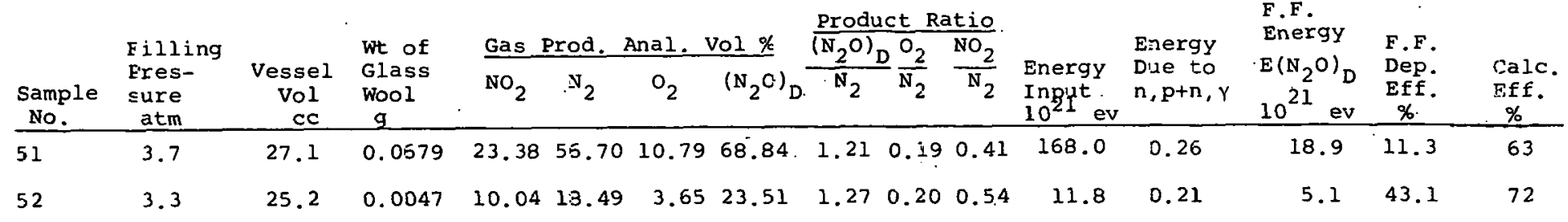




\section{TABLE VII}

\section{FISSION FRAGMENT ENERGY DEPOSITION}

$$
\begin{gathered}
\text { EFFICIENCY OF U-CONTAINING METAL FOILS } \\
\mathrm{N}_{2} \mathrm{O} \text { Dosimetry }
\end{gathered}
$$

$\begin{aligned} \text { Temperature } & 25^{\circ} \text { to } 30^{\circ} \mathrm{C} \\ \text { Vessel Volume } & 16.5 \text { to } 33.0 \mathrm{CC} \\ \text { In-pile Time } & 1 \mathrm{hr} \\ \text { Flux } & 6.7 \text { to } 9.5 \mathrm{n} / \mathrm{cm}^{2} / \mathrm{sec}\end{aligned}$

Foil

Sample

$\frac{\text { No. }}{27.6 \% \text { U-72.4\% AI Alloy Foil }}$

36

38

40

41

$1 \mathrm{~B}$

$2 \mathrm{~B}$

$35 B$

$34 \mathrm{~B}$

$39 B$
$3 \cdot \frac{1}{3 \cdot 6}$

3.7

4.2

3.3

3.7

4.5

3.8

2.5
45.7

7.6

6.3

27.9

7.6

12.7

25.4

30.5

45.7
Thickness

Range

$t / R^{(1}$.

3. 34

0.55

0.46

2.04

0.55

0.93

1.85

2.23

3.34
Deposition Efficiency $\epsilon, \%$

7.9

23.4

39.3

14.5

29.9

26.7

20.6

15.4

9.1
Unperturbed Efficiency

$\epsilon, \%$

9.5

28.1

47.1

17.4

35.9

32.0

24.7

18.5

10.9

$18.2 \%$ U-81.8\% Pd Alloy Foil

$\begin{array}{rrr}75 \mathrm{~B} & 2.7 & 1.3 \\ 76 \mathrm{~B} & 2.4 & 4.5 \\ 77 \mathrm{~B} & 3.1 & 9.2 \\ 78 \mathrm{~B} & 3.5 & 13.7 \\ 82 \mathrm{~B} & 40.6 & 5.1 \\ 83 \mathrm{~B} & 19.0 & 5.1 \\ 91 \mathrm{~B} & 3.0 & 5.1 \\ 93 \mathrm{~B} & 29.9 & 5.1 \\ & (1 \quad \text { Average range of F.F. }=\mathrm{R} \\ & \text { U-AI foil }=13.7 \mu \\ & \text { U-Pd foil }=6.1 \mu\end{array}$

0.21

52.4

63.0

0.74

1.51

2.26

0.84

0.84

0.84

0.84

20.3

9.3

7.8

22.4

23.0

20.9

29.8

24.4

11.2

9.4

25.1

9
4
4
1
1


TABLE VIII

MAXIMUM EFFICIENCY OF FISSION FRAGMENT ENERGY DEPOSITION

OBSERVED IN THIS STUDY

Fission Source

U-glass Fiber

U-glass Wool

$27.6 \%$ U-Al AlloY

18. $3 \%$ U-Pd Alloy

\begin{tabular}{|c|c|}
\hline $\begin{array}{c}\text { Thickness } \\
t \\
\end{array}$ & $\begin{array}{c}\text { Thickness } \\
\text { Range } \\
t / R \\
\end{array}$ \\
\hline $0.29 \mathrm{mg} / \mathrm{cm}^{2}$ & - \\
\hline $0.19 \mathrm{mg} / \mathrm{cm}^{2}$ & - \\
\hline $6.3 \mu$ & 0.46 \\
\hline $1.3 \mu$ & 0.21 \\
\hline
\end{tabular}

Efficiency. Observed

in Capsule $\varepsilon, \%$

Unperturbed

Efficiency

$\epsilon, \%$

39.0

61.3

43.1

39.3

47.1

52.4

63.0 
TABLE IX

FISSION FRAGMENT IRRADIATION OF $77 \% \quad \mathrm{~N}_{2}+23 \% \quad \mathrm{O}_{2}$

GAS FOR A FIXED ARRAY OF GLASS FIBER

Temperature $25^{\circ}$ to $30^{\circ} \mathrm{C}$

Vessel Volume 19.8 to $33.1 \mathrm{cc}$

In-pile Time 0.5 to $1.0 \mathrm{hr}$

Flux 6 to $7 \times 10^{12} \mathrm{n} / \mathrm{cm}^{2} / \mathrm{sec}$

\begin{tabular}{|c|c|c|c|c|c|}
\hline \multirow{2}{*}{$\begin{array}{l}\text { Sample } \\
\text { No. }\end{array}$} & \multirow{2}{*}{$\begin{array}{l}\text { Filling } \\
\text { Pressure } \\
\text { atm }\end{array}$} & \multirow{2}{*}{\multicolumn{2}{|c|}{$\begin{array}{l}\text { Gas Product } \\
\text { Conc. by } \mathrm{Vol} \\
\% \mathrm{NO}_{2} \\
\end{array}$}} & \multicolumn{2}{|c|}{$\begin{array}{c}\text { Fission Fragment } \\
\text { G values }\end{array}$} \\
\hline & & & & $\mathrm{NO}_{2}$ & $\mathrm{~N}_{2} \mathrm{O}$ \\
\hline $17 \mathrm{~B}$ & 68.0 & 0.12 & 0.12 & 1.03 & 1.37 \\
\hline $53 B$ & 47.6 & 0.10 & 0.12 & 0.49 & 0.85 \\
\hline $58 B *$ & 15.9 & 0.15 & 0.16 & 0.49 & 0.52 \\
\hline 3 & 3.7 & 0.24 & 0.48 & 0.67 & 1.42 \\
\hline 7 & 3.7 & 0.81 & 1.00 & 1.21 & 1.53 \\
\hline 8 & 3.8 & 0.92 & 0.88 & 1.65 & 1.62 \\
\hline 9 & 2.5 & 0.69 & 0.93 & 0.50 & 0.70 \\
\hline 12 & 3.1 & 1.07 & 0.90 & 0.99 & 0.85 \\
\hline 13 & 2.9 & 0.75 & 1.05 & 0.80 & 1.16 \\
\hline 14 & 3.0 & 1.03 & 0.80 & 0.77 & 1.00 \\
\hline 20 & 2.9 & 0.47 & 0.52 & 0.78 & 0.89 \\
\hline 25 & 2.9 & 0.65 & 1.70 & 0.76 & 2.10 \\
\hline
\end{tabular}

* Flux $=10.4 \times 10^{12} \mathrm{n} / \mathrm{cm}^{2} / \mathrm{sec}$ 
TABLE $X$

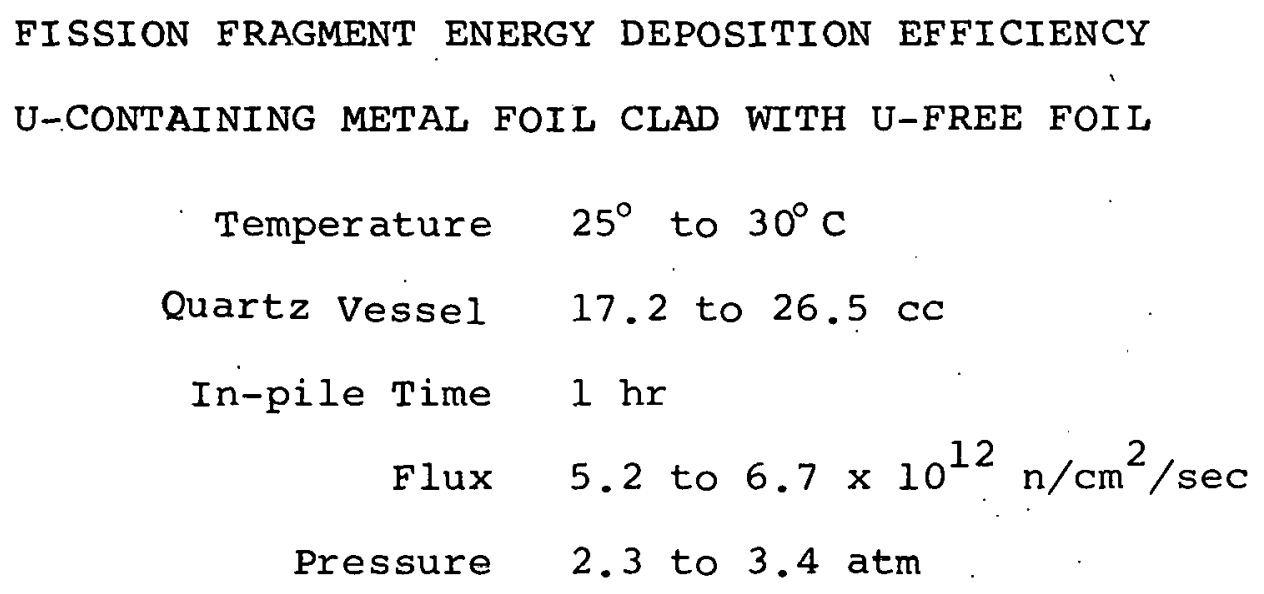

7.6

0.93

0.65

1.86

1.48

0.93

0.65

Efficiency

12.7
8.9

25.4

20.3

12.7

8.9

2.92

1.78 ..

2.54

0.42

1.78

1.78

5.08

1.78

10.16

0.83

1.67

$\epsilon, \%$

9.1

8.8

10.8

7.6

$9 . .6$

9.6

$87 \mathrm{~B}$
$86 \mathrm{~B}$

26.5
19.1
16.4
4.8 
TABLE XI

SUMMAFY OF $\mathrm{NO}_{2}$ AND $\mathrm{N}_{2} \mathrm{O}$ YIELDS FROM IRRADIATION OF

$75 \%$ to $80 \% \mathrm{~N}_{2}$ AND $20 \%$ to $25 \% \mathrm{O}_{2}$ GAS MIXTURES

$$
\text { Temperature } 25^{\circ} \text { to } 30^{\circ} \mathrm{C}
$$

Type of

\section{Radiation}

This Work

Co-60

Pile $(n, p+n, i)$

Fission Fragments

\begin{tabular}{|c|c|c|c|c|c|}
\hline $\begin{array}{l}\text { Intensity } \\
10^{21} \mathrm{ev} / \mathrm{g} / \mathrm{hr}\end{array}$ & $\begin{array}{l}\text { Pressure } \\
\text { Range } \\
\text { atm } \\
\end{array}$ & $\begin{array}{l}\text { Conc. } \mathrm{NO}_{2} \\
\text { Vol. } \%\end{array}$ & $\mathrm{G}\left(\mathrm{NO}_{2}\right)$ & $\mathrm{G}\left(\mathrm{N}_{2} \mathrm{O}\right)$ & $\begin{array}{l}\text { Ratio } \\
\mathrm{NO}_{2} / \mathrm{N}_{2} \mathrm{O} \\
\end{array}$ \\
\hline 0.06 & $8.0-73$ & $0.1-0.2$ & $0.6-0.8$ & $0.1-0.2$ & $3.4-9.3$ \\
\hline 1.6 & $0.6-73$ & $0.2-9.8$ & $0.6-0.8$ & $0.3-0.6$ & $1.1-2.8$ \\
\hline 27.0 & $2.5-68$ & $0.8-1.1$ & $0.5-1.7$ & $0.5-2.1$ & $0.4-1.2$ \\
\hline
\end{tabular}

Other Reported Nork (Ref.)

Co-60 Gamma $(23,24)$

Pile $(n, p+n ; Y)$

(14)

Alpha

Fission Fragments(26)

$\begin{array}{lllll}1.0-150 & 0-2.0 & 1.6-5.6 & 0.6-3.2 & 1.7-2.7 \\ 0.8-25\left(175^{\circ} \mathrm{C}\right) & 0.7-11.2 & 0.3-5.0 & 0.1-1.5 & 1.0-2.7 \\ 0.0-10 & 3.0 & & \\ 8.0-30\left(100^{\circ} \mathrm{C}\right) & & 0.9 & & \\ 27\left(250^{\circ} \mathrm{C}\right) & 0.9-1.9 & & \\ 68\left(200^{\circ} \mathrm{C}\right) & 3.1 & \end{array}$




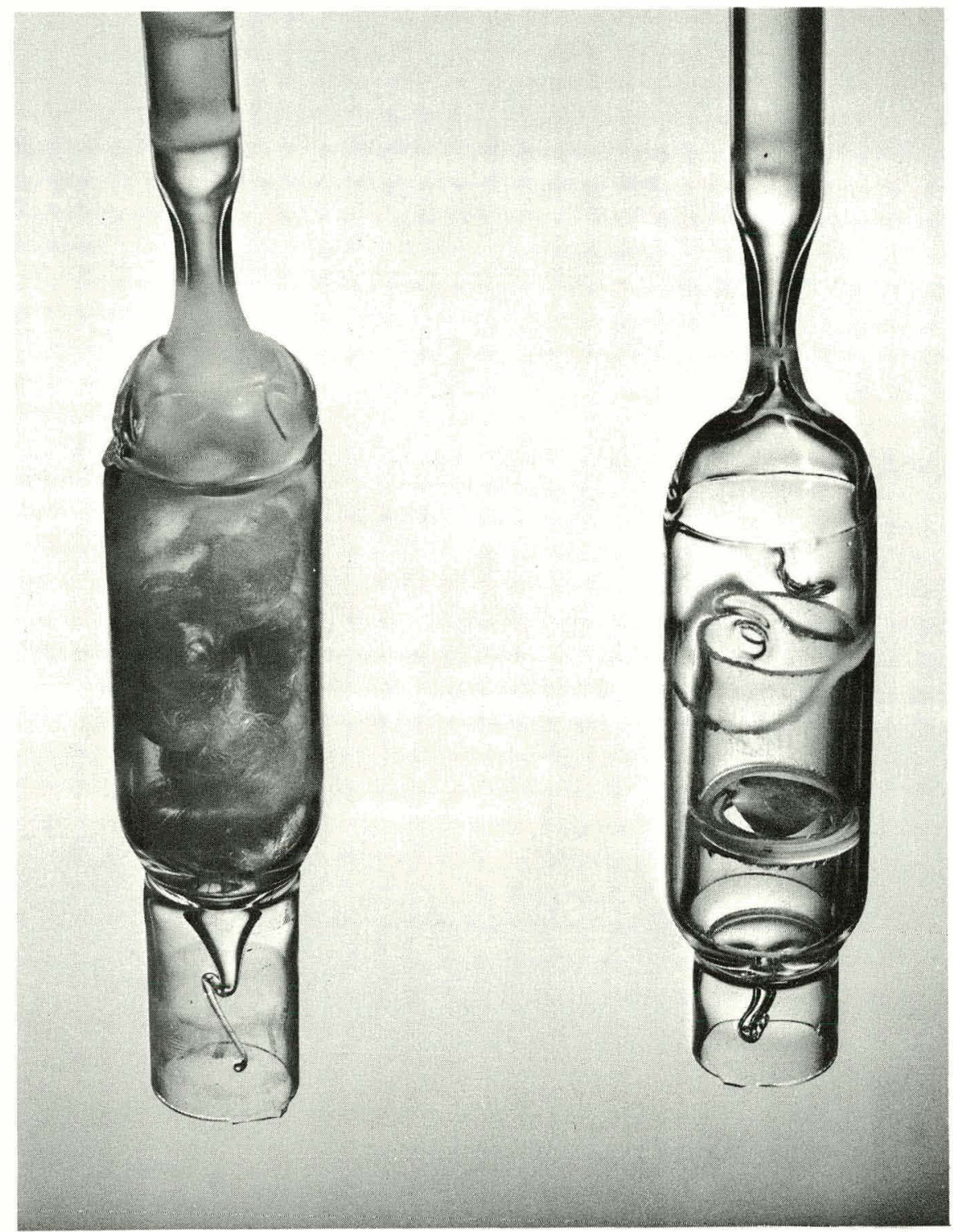

Figure 1 Quartz Break Seal Irradiation Vessel. Left: Ucontaining glass wool fission source. Right: Ucontaining metal foil fission source. 


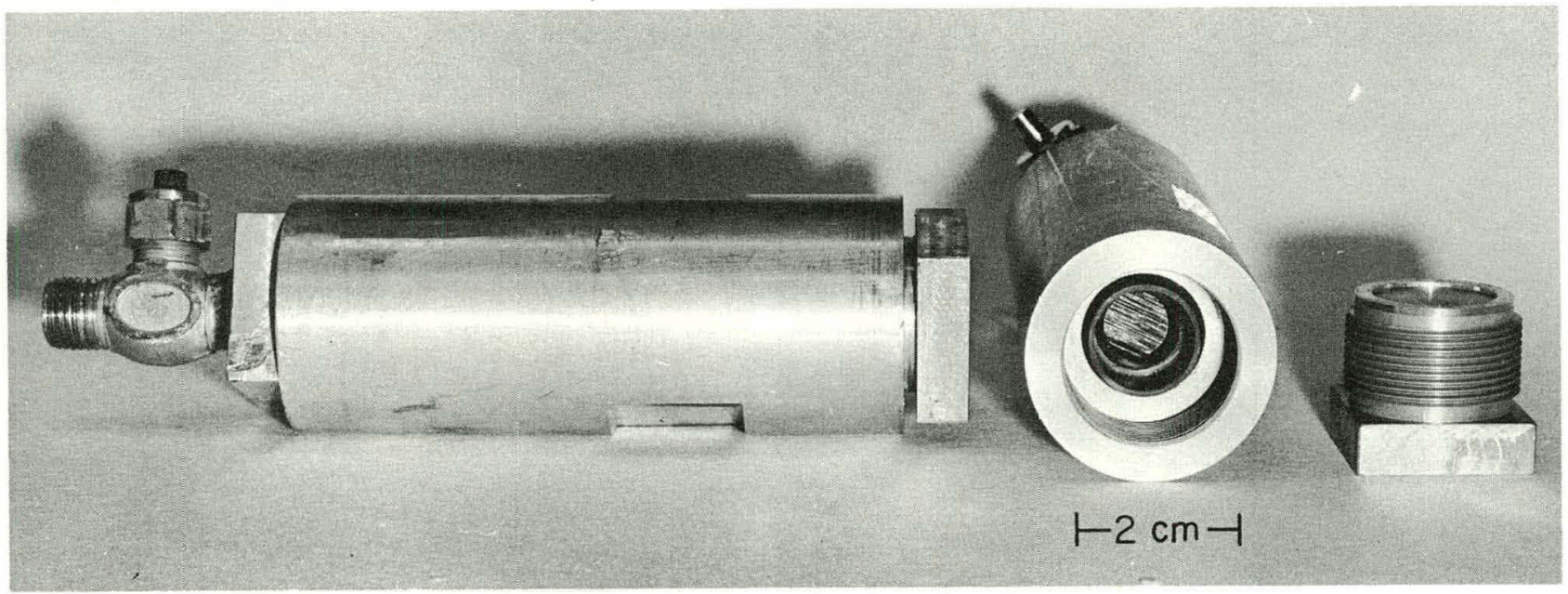

Figure 2

Aluminum Irradiation Pressure Vessel. U-containing glass fiber fission source in an oriented array shown inside the vessel. 


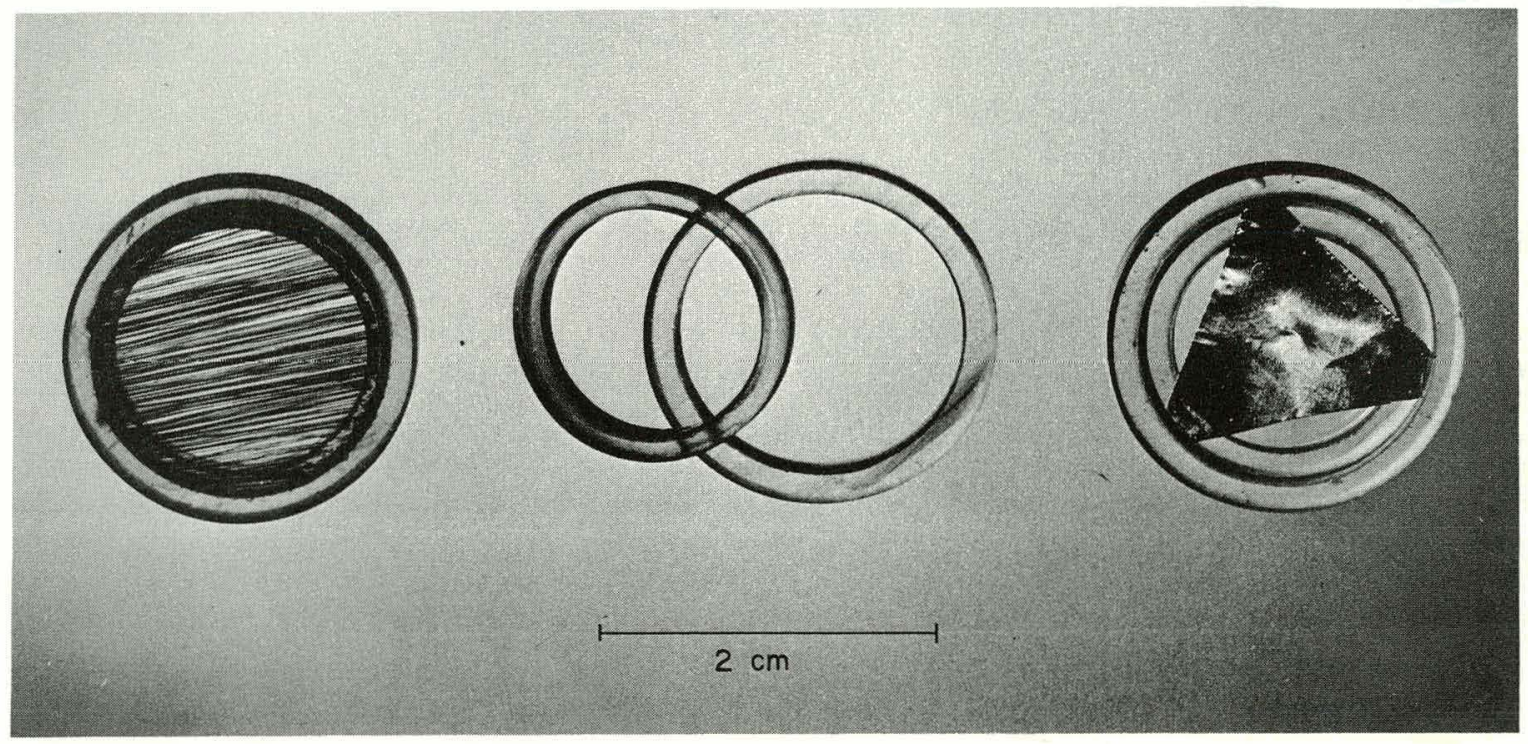

Figure 3

U-containing Fission Source Discs. Bight: U-Al foil $0.5 \mathrm{mil}$ thick containing $25.8 \mathrm{w} / \mathrm{O} \mathrm{U}^{23}$. Left: Uglass fiber 35 an oriented fixed array containing $36.8 \mathrm{w} / \mathrm{O} \mathrm{U}^{235}$. 


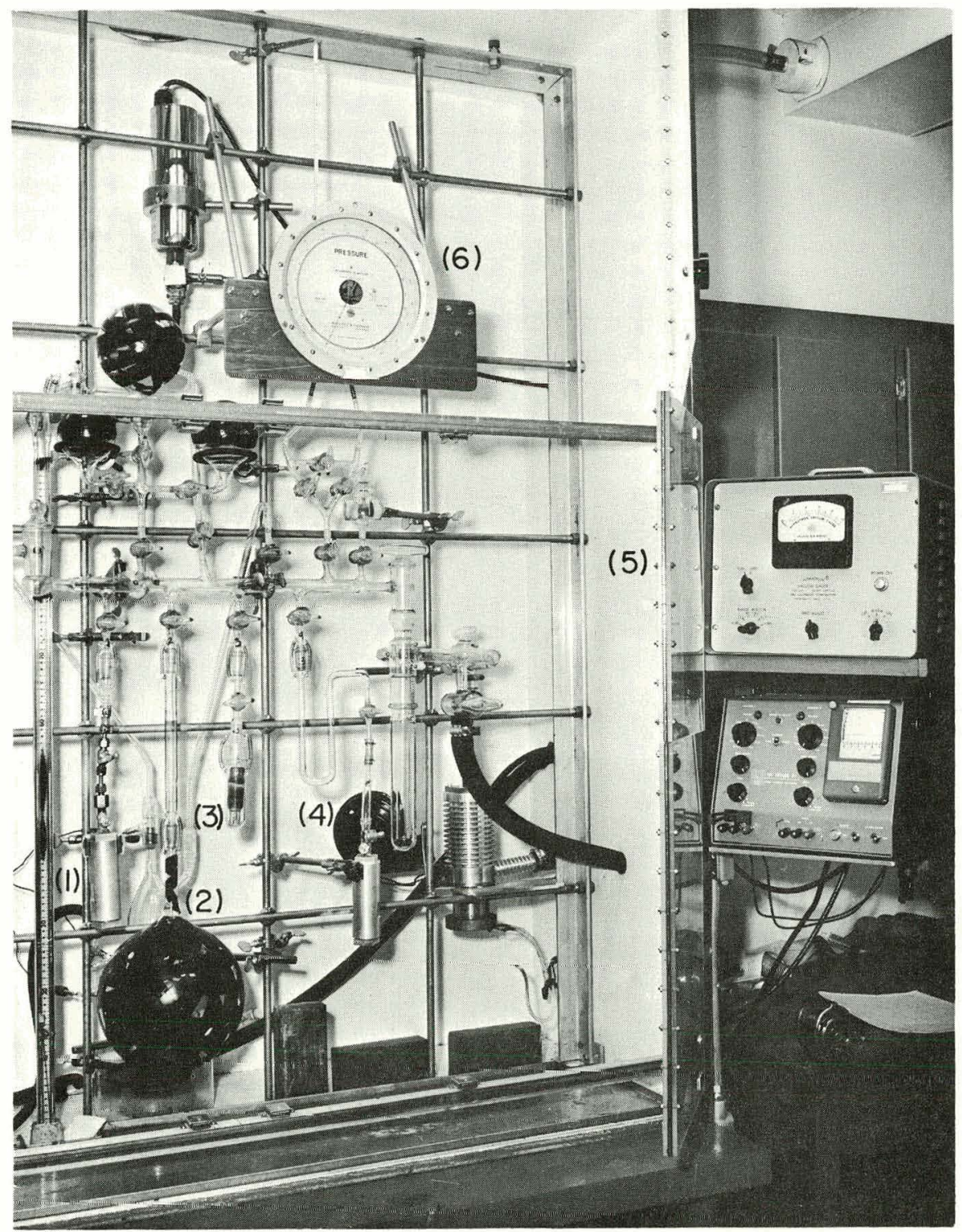

Figure 4

Vacuum Rack. On rack from left to right - (1) Al pressure container in filling position, (2) expansion bulb for high pressure runs, (3) glass vessel containing break seal quartz capsule, (4) Al pressure container with transfer trap, (5) Alphatron gauge and recorder, and (6) Wallace \& Tiernan Bourdon gauge. 


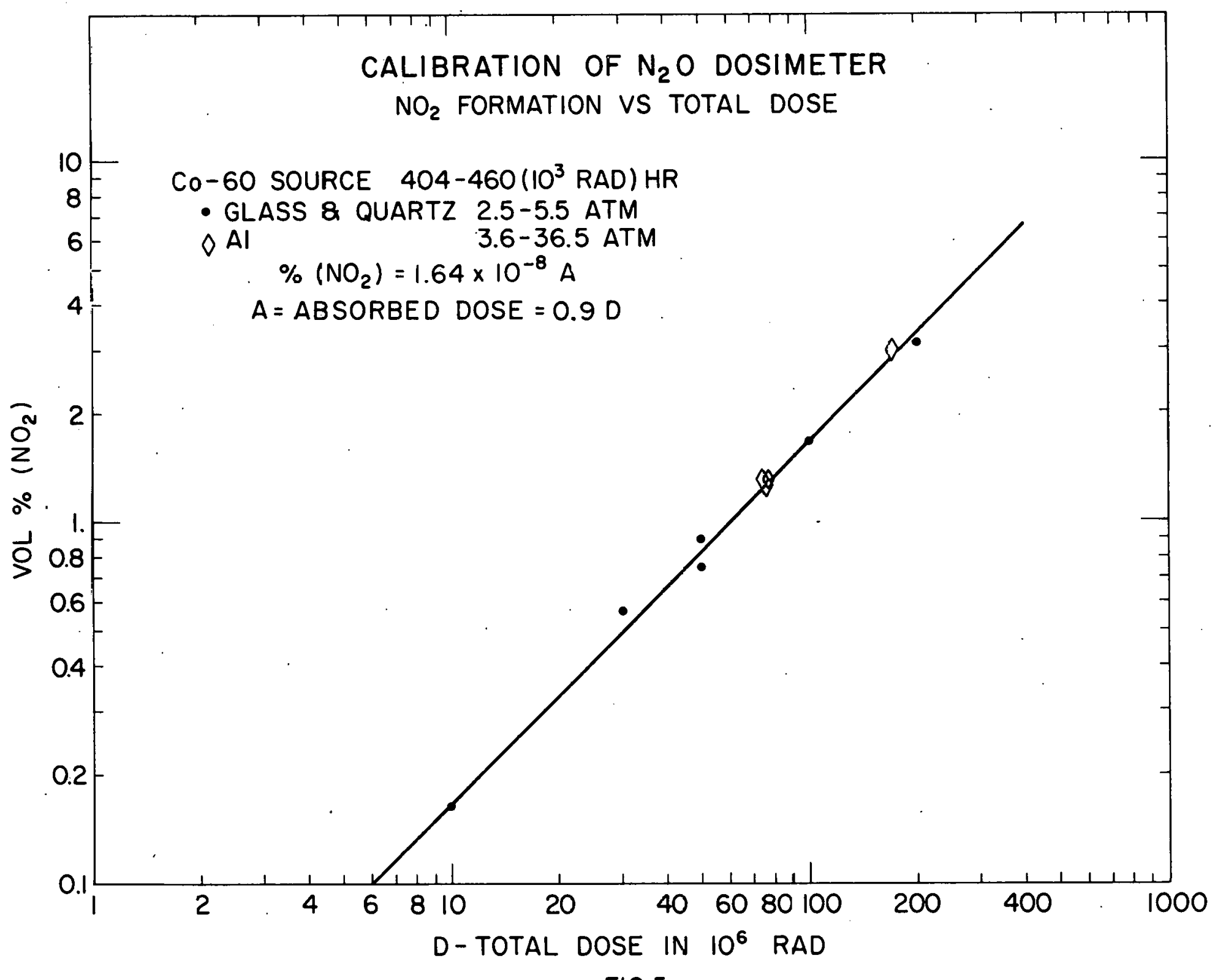

FIG. 5 


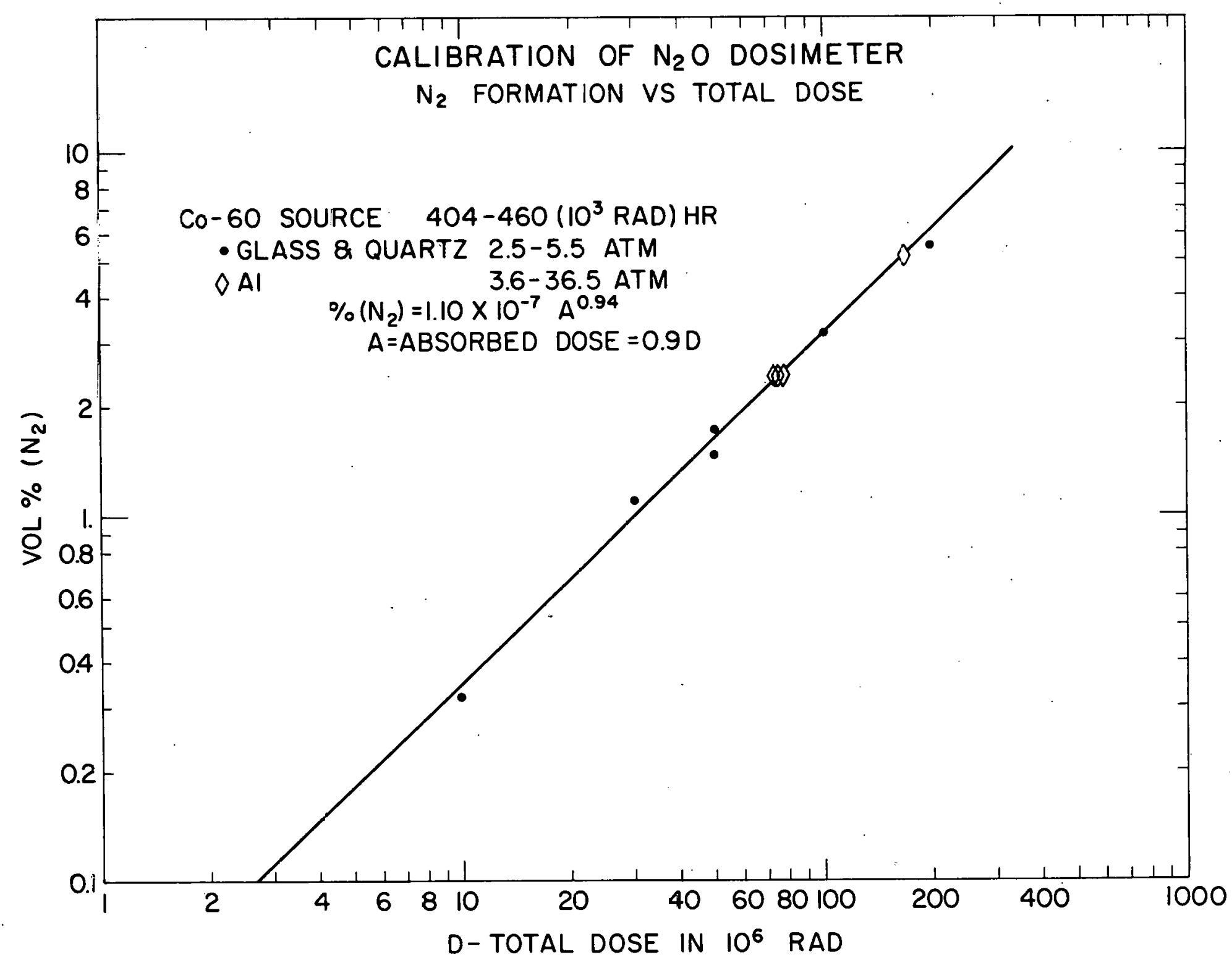

FIG. 6 


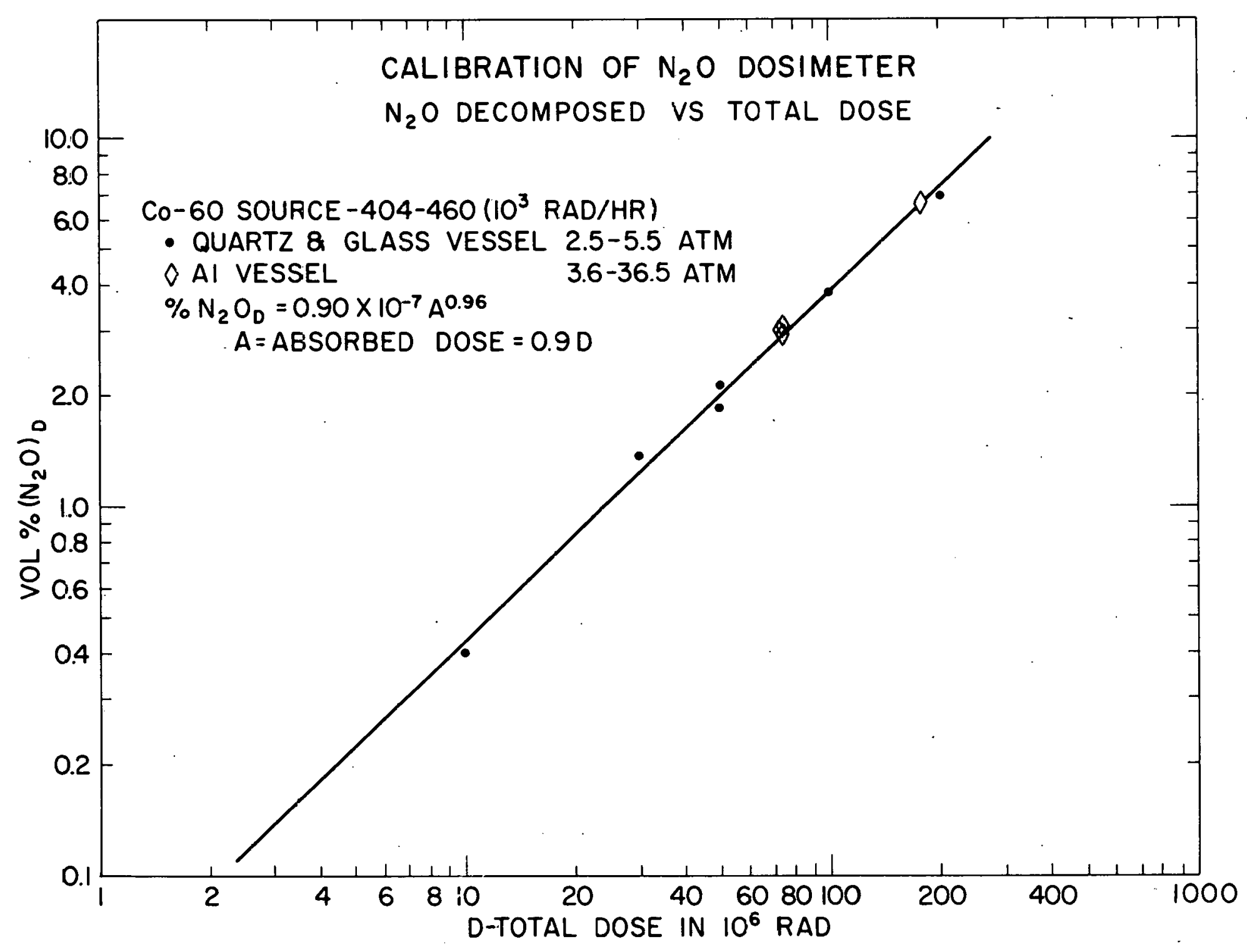

FIG 7 


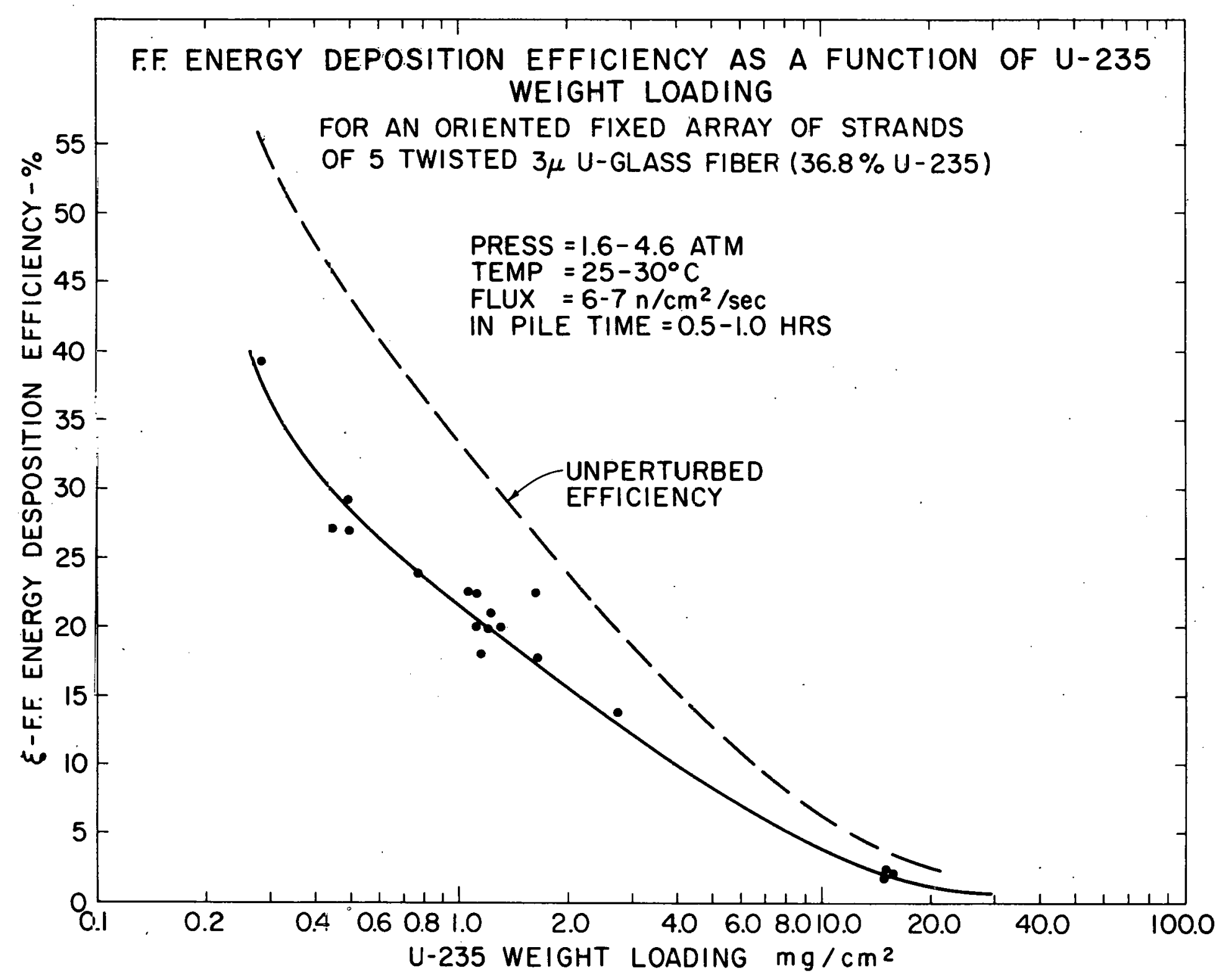

FIG. 8 


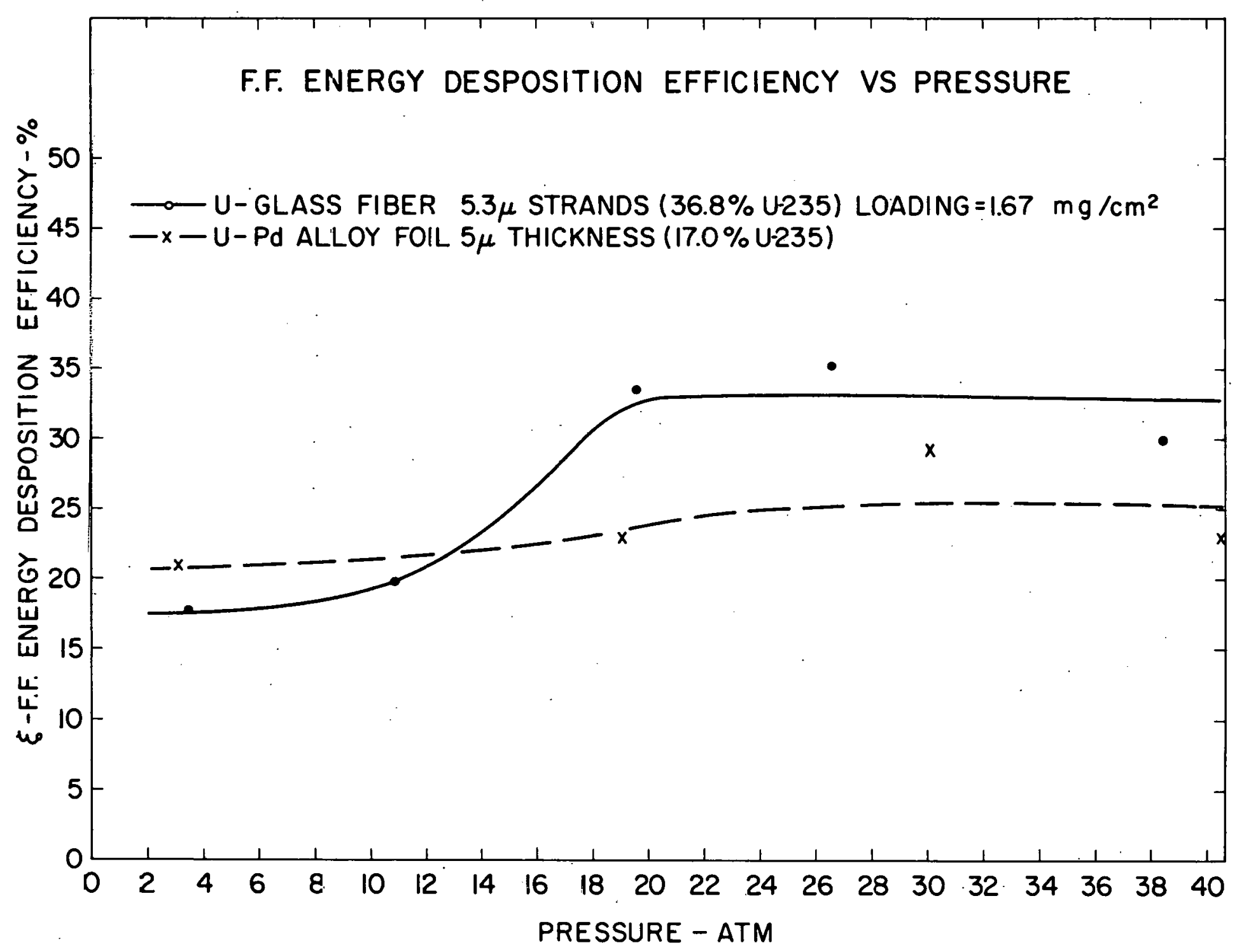

FIG. 9 


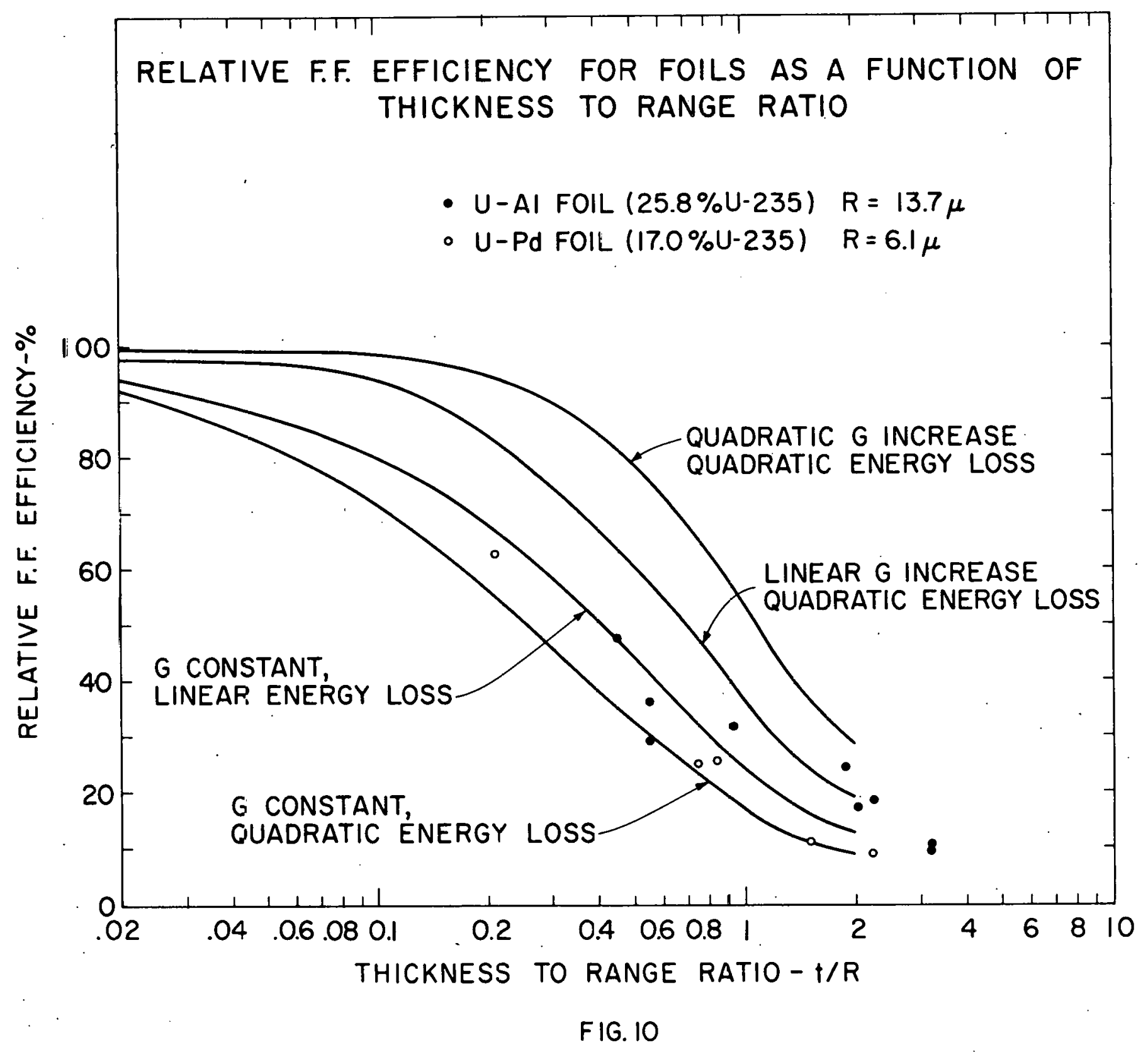




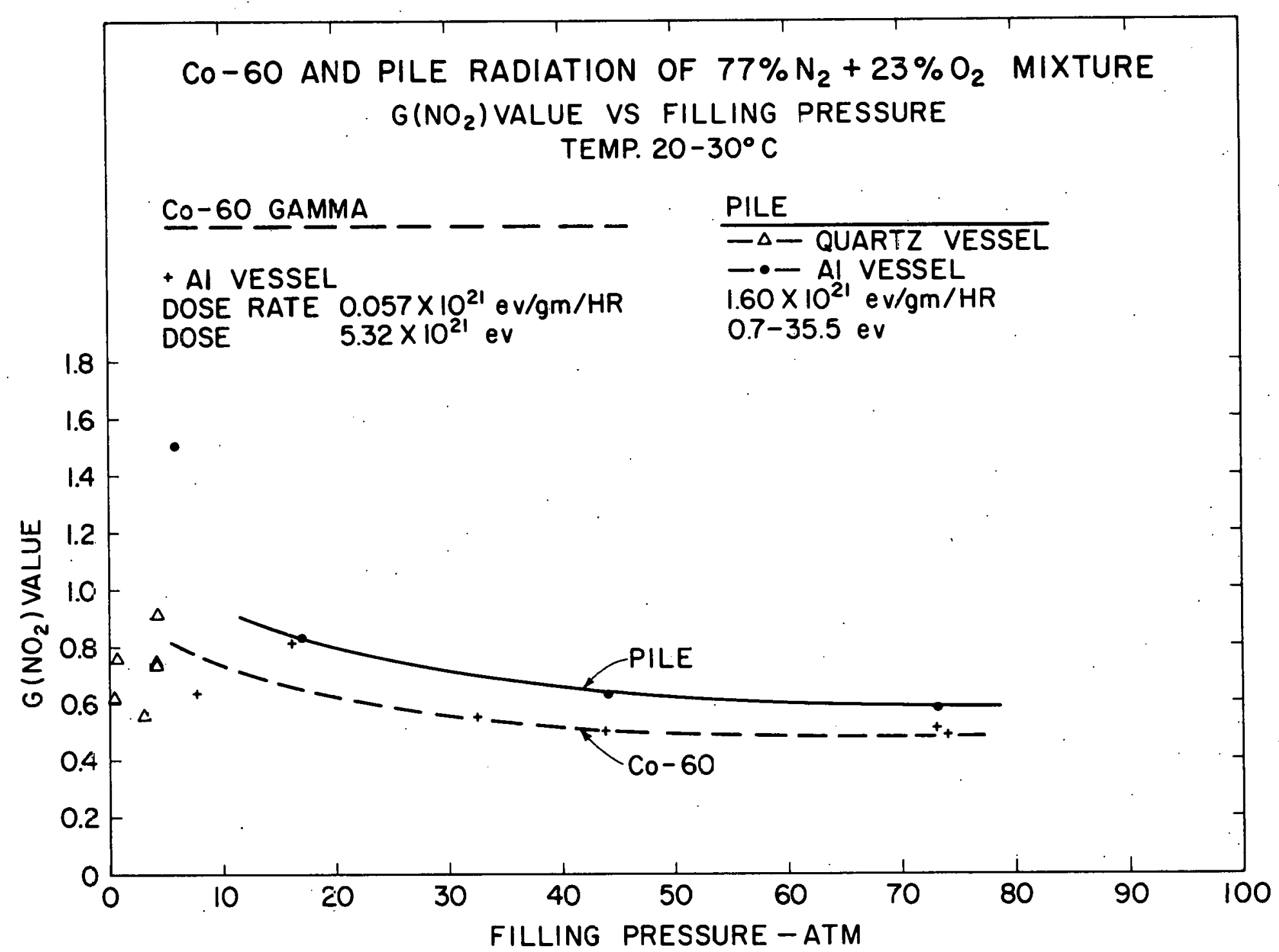

FIG. II 


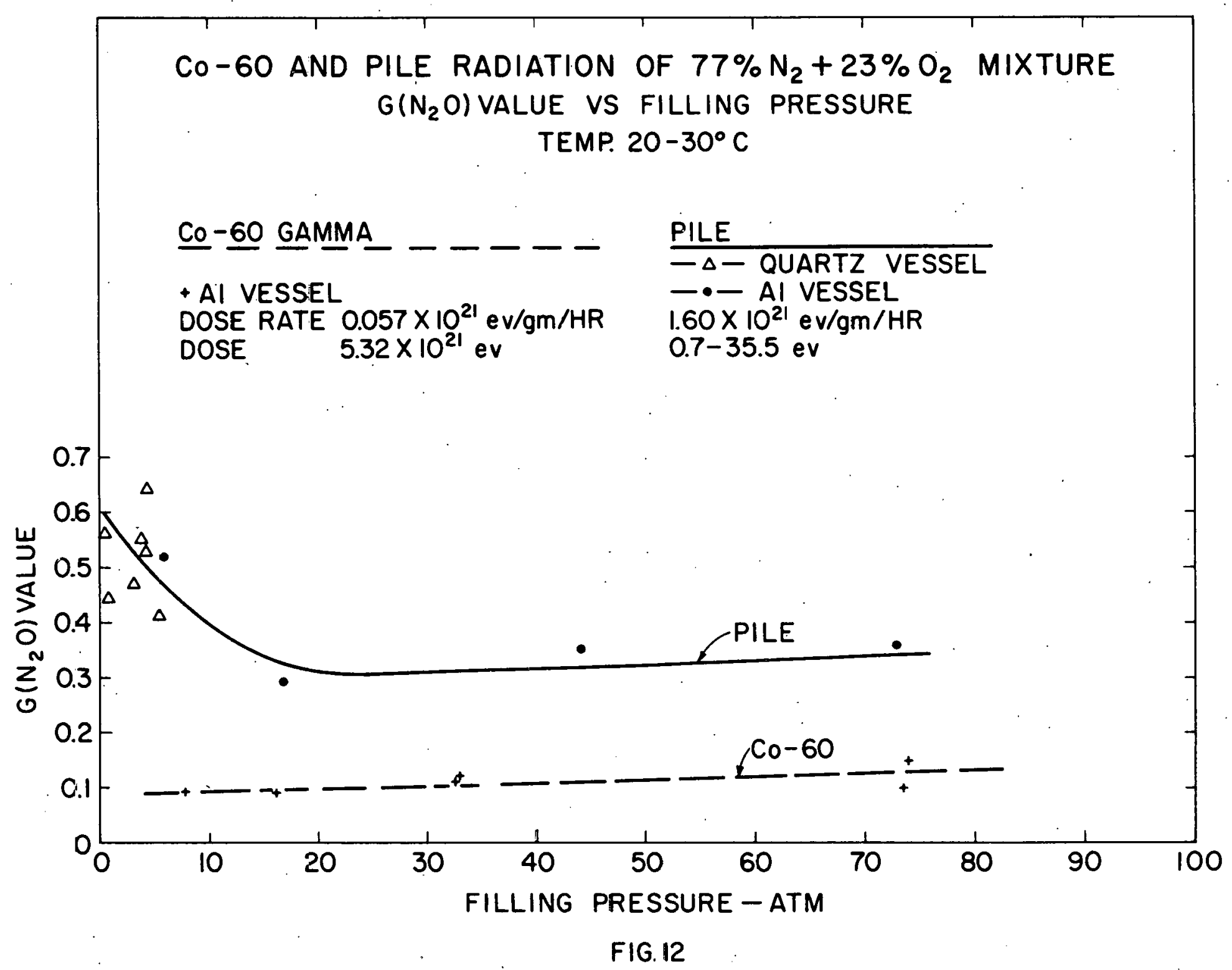




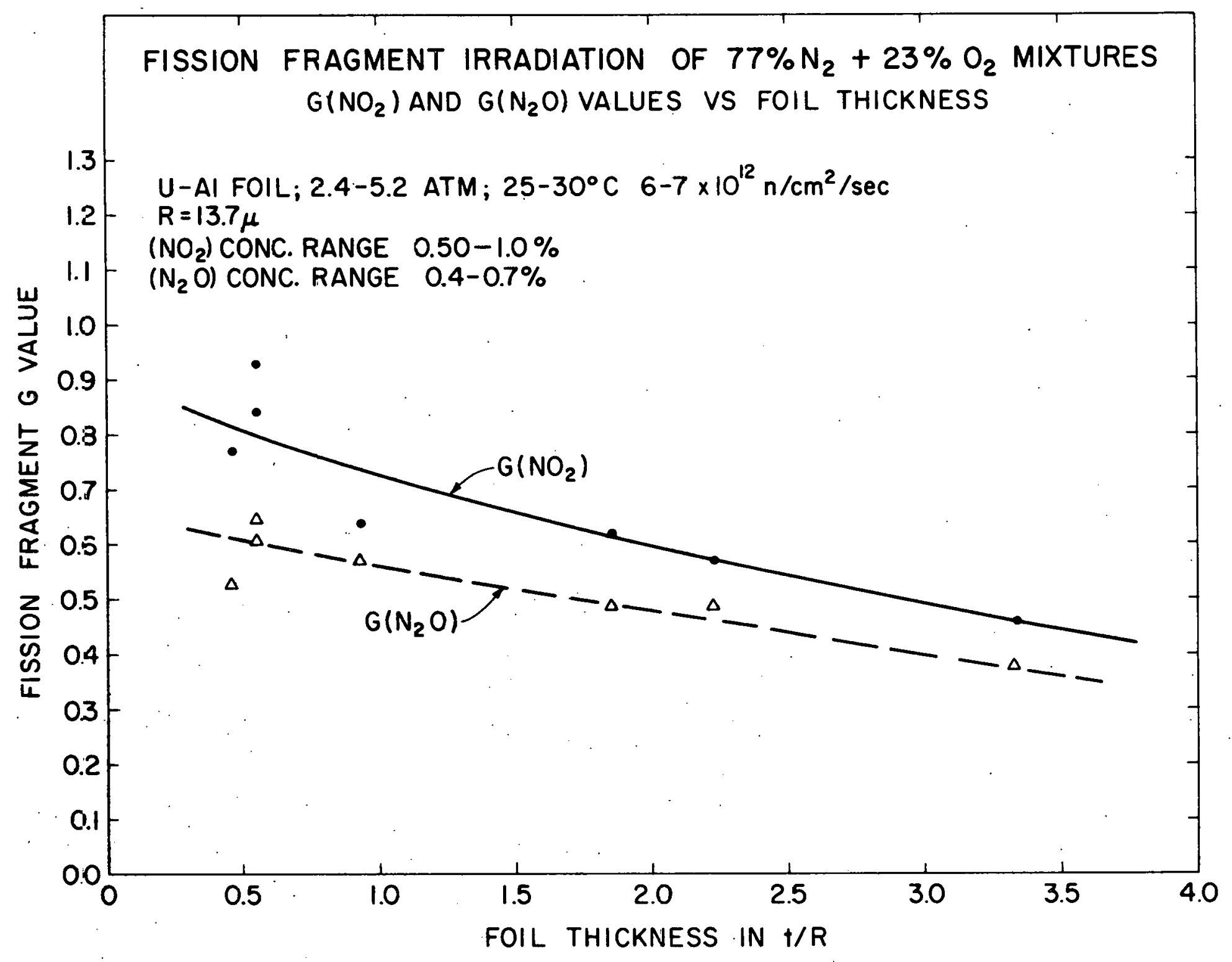

FIG. I3 


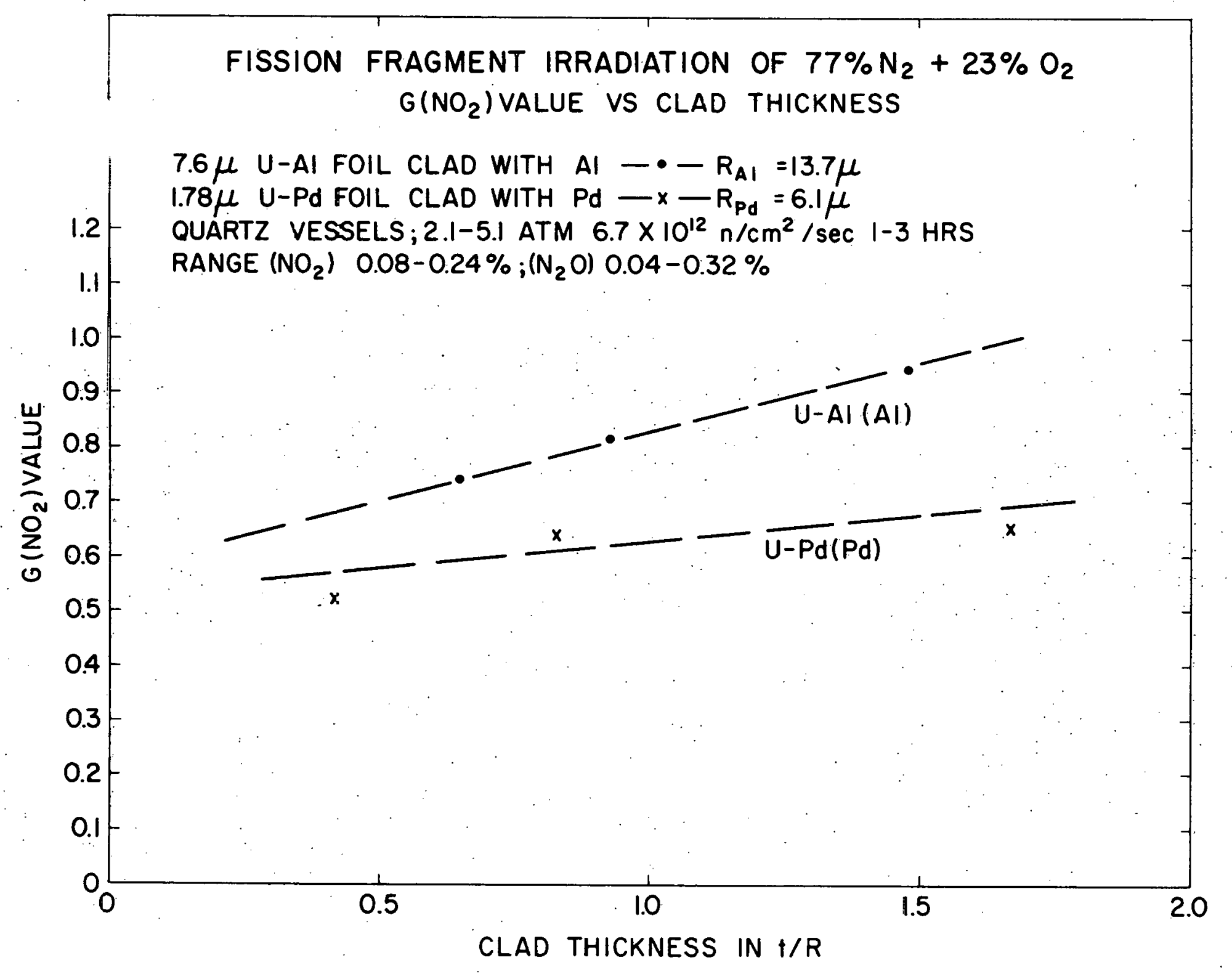

FIG. 14 